\title{
CELS
}

CELSI Discussion Paper No. 56

\section{DRIVERS OF CULTURAL} PARTICIPATION OF IMMIGRANTS: EVIDENCE FROM AN ITALIAN SURVEY

February 2020

ENRICO BERTACCHINI ALESSANDRA VENTURINI ROBERTO ZOTTI 


\title{
DRIVERS OF CULTURAL PARTICIPATION OF IMMIGRANTS: EVIDENCE FROM AN ITALIAN SURVEY
}

\author{
CELSI Discussion Paper No. 56 \\ February 2020
}

\author{
Enrico Bertacchini \\ University of Turin
}

\begin{abstract}
Alessandra Venturini
University of Turin
\end{abstract}

Roberto Zotti

University of Turin

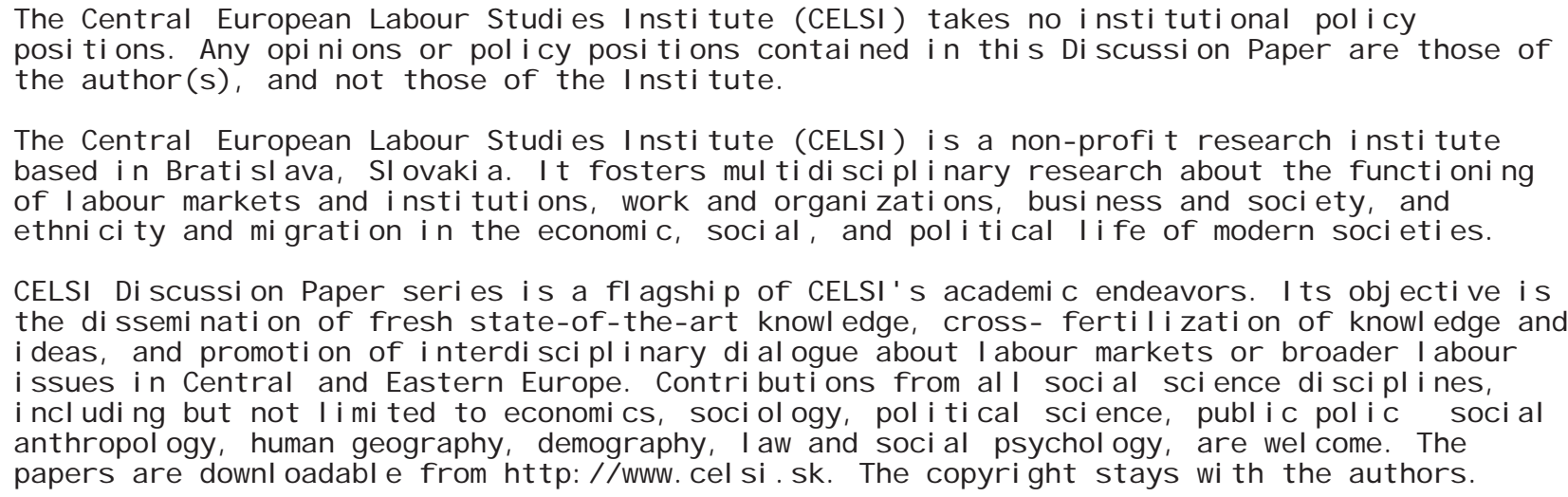

Central European Labour Studies Institute (CELSI) 
CELSI Discussion Paper No. 56

February 2020

\section{ABSTRACT \\ Drivers of cultural participation of immigrants: evidence from an Italian survey}

The paper aims to explore the drivers of immigrants' participation to cultural and leisure activities in host countries. First, we discuss how the main analytical approaches on cultural participation can be extended to incorporate factors specific to migrants' characteristics and behaviour, namely dimensions of proximity to the native population's culture and the level of integration in the host society. Secondly, we investigate migrants' propensity for consumption of cultural and leisure activities using data of a special national survey on Income and Living conditions (2011-2012) on foreign households in Italy. Italy represents an interesting case because it is a recent immigration country, making the analysis particularly suitable for studying the behaviour of first-generation immigrants. Our findings suggest that language proficiency, duration of stay and intention to remain in the host country significantly increase the probability to access various types of 1eisure and cultural activities. Interestingly, after controlling for standard individual predictors, several dimensions of an immigrant's cultural background and proximity with the culture of the host society still significantly explain variation in cultural participation rates, confirming that cultural differences play a role in migrants' cultural consumption choice.

Keywords: cultural participation, migrants, cultural proximity

JEL Classification: Z1 1, J15, J61

\section{Corresponding Author:}

Alessandra Venturini

University of Turin; Associate MPC-EUI, Associate Celsi

alessandra.venturini@unito.it

*Acknowledgements

The research explores the drivers of immigrants' participation to cultural and leisure activities in Italy. After controlling for the individual characteristics, language proficiency, duration of stay and intention to remain in the host country are the main drivers of cultural activities. 


\section{Introduction}

Migration has become in the last decades one of the most overarching phenomena at the global level and immigrants account today more than 10 percent of the total population in several advanced countries (United Nations, 2016). Consistently with the relevance of the phenomenon, much of the academic research and policy debate have focused on patterns and determinants of inclusion of migrants at receiving societies along several dimensions. A large body of literature has focused on the economic integration of immigrants, in particular labor market outcomes (i.e. Chiswick, 1978; Borjas, 1995). Other works have addressed socio-cultural dimensions, such as perceived national or ethnic identity of immigrants (Dustmann, 1996; Bisin et al., 2008, 2016), socialization trajectories or the assimilation of cultural values and habits (De Palo et al., 2007; Algan et al. 2013; Diehl et al., 2016).

Despite this extensive evidence, research has paid little attention to a relevant sphere of human socialization and integration, that is the extent and how migrants engage in leisure, cultural and arts activities in the receiving country. In particular, there is a substantial lack of evidence on immigrants' patterns of cultural consumption, their tastes and preferences for cultural goods of the destination country, or the way cultural preferences and cultural consumption are associated with the socioeconomic integration process. This can be partly due to the fact that migrants' cultural integration in the host society has been often considered, according to different conceptual views in social sciences (assimilation theory, multiculturalism and structuralism), as the outcome of medium and long-term intergenerational dynamics, overlooking the role of cultural participation as a horizontal channel of cultural transmission.

At the same time, studies on cultural participation have rarely addressed immigrants' behavior in cultural and arts practices. Although cultural economic and sociological literature has extensively analyzed individual determinants of arts and cultural participation (i.e. Seaman, 2006; AtecaAmestoy, 2008; Falk \& Katz-Gerro, 2016), the empirical works in these fields have generally relied on representative samples of the population at the natioal level, but not statistically stratified across ethnic communities. Further, when studies have considered the effect of ethnicity on cultural participation (Gray, 2003; Van Wel et al., 2006; Katz-Gerro et al. 2009; Novak-Leonard, 2015) this has been done mainly on multicultural societies (such as Israel, US and the Netherlands) or focusing on differences in cultural participation between first and second-generation immigrants (NovakLeonard, 2015).

The paper aims to explore the patterns and determinants of cultural participation of immigrants, shedding light on individual factors that influence immigrants' decision to engage in highbrow and lowbrow cultural activities offered at the destination country. Firstly, we critically reconsider the 
main tenets of the literature on cultural participation by discussing whether and how they could be extended to address peculiar factors influencing immigrants' cultural consumption, namely cultural proximity between migrants' country of origin and destination and other dimensions of immigrants' socio-economic integration. Secondly, we empirically explore the drivers of cultural participation by using data from a unique survey conducted by the Italian National Institute of Statistics (ISTAT) in 2011-2012 on living conditions of households with foreign-born members.

Italy represents an interesting case study to explore the phenomenon for two main reasons. Unlike other western European countries, Italy, as a destination country, is characterized by a more recent history of immigration flows (Venturini, 2004) which makes possible to better analyse the behavior of first-generation immigrants and their degree of adaptation in the new context, isolating it from other factors deriving from a more accumulated history of migration flows. In addition, the Italian language is scarcely spread globally, both as a first and second language, enabling to better isolate the effect that linguistic barriers have on immigrants' cultural participation in the destination country.

Our findings unveil several insights on the drivers of migrants' cultural participation. First, while cultural participation studies have generally found mixed evidence on the age-cultural consumption relationship depending on the type of cultural activities considered, we find that younger generations tend to have a higher propensity to engage in leisure and cultural activities. Secondly, even after controlling for socioeconomic and demographic characteristics, the level of immigrants' integration in the host society, measured along several dimensions, is a significant driver of the propensity to engage in cultural and leisure activities available in the country. Further, the heterogeneity in migrants' cultural background and proximity with native population's culture is another statistically significant factor to explain variation in participation rates depending on the type of activity considered.

The paper is organized as follows: Section 2 contextualizes immigrants' behaviour in cultural participation research; Section 3 present key facts of immigration patterns in Italy; Section 4 describes data and variables; in Section 5 we present the empirical models and discuss the results of the econometric analysis, while Section 6 concludes.

\section{Identifying drivers of immigrants' cultural participation}

An extensive literature in both economics and sociology has addressed both theoretically and empirically the determinants of cultural participation. From the economic perspective, it has long been recognized how the consumption of cultural goods and services is explained, besides standard 
factors linked to market conditions and households' time and economic resources, by the accumulation of human capital and the process of taste cultivation (Stigler and Becker, 1977; Gray, 2003, Seaman, 2006). The sociological approach emphasizes, in turn, the role of cultural capital in shaping individual tastes and society's cultural stratification, that is the relationship between cultural consumption patterns, the competencies they bring, and how this translates into structures of power and inequality in society (Yaish and Katz-Gerro, 2010). With this perspective, the sociological literature has contributed on highlighting how the distinction between highbrow and lowbrow cultural products shapes consumption patterns of different social groups (Levine, 1988) or identifying more articulated consumer profiles in cultural markets, such as the "omnivores" and "univores" (Peterson, 2005).

From an empirical viewpoint, both the approaches help explaining how individual characteristics, namely age, income, occupational class, education, household characteristics and past cultural consumption influence preferences for cultural goods as well as affect the time, financial and intellectual constraints to engage in arts and cultural activities. Yet, despite the substantial cultural participation research, the majority of empirical works have almost exclusively focused on the heterogeneity of the population at the level of socio-economic characteristics, overlooking factors that are peculiar to migrants' characteristics in explaining the behavior of this group of population in cultural participation practices.

Crucially, relevant questions remain unaddressed when dealing with migrants' participation in cultural and arts activities. A first question relates to how the level of integration and assimilation in the new society is likely to affect immigrants' cultural consumption patterns. As for other types of migrants' choices and behaviour in the host country, participation in arts and cultural activities can be conceived as the outcome of cultural integration or assimilation processes. According to Dustmann (1996), change in the environment as radical as an international migration necessarily implies a process of habituation, where changes in consumption patterns induce changes in tastes and social habits. Integration in the new society in turn depends on the degree of exposure to the new environment and on the level through which a migrant is able to access knowledge and information about the new social structure. Exposure is mainly reflected in the years of residence in the destination country and the literature has commonly found this factor to be positively associated with higher levels of economic and social integration (Chiswik, 1991; Venturini and Villosio, 2008). Similarly, proficiency in the language of the host country is considered a significant determinant in all studies on economic assimilation of migrants (Dustmann and Fabbri, 2003), as it captures the ability to communicate with and access knowledge of the incumbent population. Therefore, we hypothesize that the years of residence and the proficiency in the natives' language are both factors positively 
related to the migrants' adaptation to local cultural traits and the accumulation of consumption capital for cultural products of the destination country.

A second line of inquiry concerns whether, even after controlling for sociodemographic characteristics and the level of integration, heterogeneity in cultural factors and traits peculiar to immigrant communities still shape preferences for and participation to cultural and leisure activities available in the receiving society. To explore this channel, different dimensions of cultural identity of migrants and distance with the culture of the host country society can be considered. One of the most evident expressions of cultural identity and adopted proxy to measure cultural distance between two populations refers to language (Lazear, 1999). The economic literature on international trade of cultural goods (Shulze, 1999) and on cultural factors influencing migration flows (Belot and Ederveen, 2012; Adsera and Pytlikova, 2015) suggest that the linguistic proximity between the origin and the destination country would lead to a larger consumption capital by immigrants for cultural and artistic expressions of the host society, raising the appreciation for this type of products. Another dimension of cultural identity stems from the difference in religion and religiosity across migrants' groups. Religious beliefs and practices tend to define norms of conduct and behaviour that can favour or hinder the access and time dedicated to specific leisure and cultural activities influencing cultural participation rates. Interestingly, recent empirical works using also data from non Western countries (Van Eijk, 2011; Katz-Gerro et al., 2009; Katz-Gerro and Meier Jaeger, 2012) found that religious beliefs tend to not be associated with systematic differences in cultural consumption. Conversely, individuals' religiosity (defined as the intensity to attend religious services) has a significant and, in many contexts, positive impact on cultural consumption, an effect that is comparable to that of other socioeconomic factors such as education and socioeconomic status. This finding points out to an absent or weak substitution effect between time devoted to religious services and that for secular activities, including cultural consumption, and rather suggests that religiosity might signal a more active social life and intensity of social ties.

Another common measure to capture migrants' cultural identity and the distance with the native population's culture is simply the nationality of the migrant. Nationality may reflect a complex variety of cultural factors, namely values, beliefs and social habits that are hardly captured by linguistic, religious or ethnic heterogeneity alone. For example, Demset et al. (2017) found that ethnicity does serve to significantly predict about most of cultural attitudes as defined and measured by the World Value Surveys, but to an extent that varies across geographic regions and with between-group share of the variance in cultural values that is larger when using countries instead of ethnicities as reference group. 


\section{Immigration in the Italian context}

Compared to other European countries, immigration is a relatively new phenomenon for Italy (Venturini, 2004). While for most of the XX century Italy has been characterized by both emigration and internal migration flows from the less developed regions of the country, starting since the oil crisis in the 70's and 80's, it has turned to be a destination country, receiving immigrants largely from developing areas of the world and Eastern Europe. In the last three decades, immigration flows have grown steadily and with high annual growth rates, making Italy one of the European countries that has experienced the largest inflow of immigrants both in absolute levels and as a percentage of resident population (OECD, 2014; Reyneri, 2007). In the 1991 census, the share of legal immigrants in the Italian population was still only 0.5 per cent, whereas it had risen to 6,8 per cent in the 2011 census. By 2017 , foreign migrants represented about $10 \%$ of the population and $12 \%$ of the total workforce; $60 \%$ of them were located in the North, $25 \%$ in the Centre, and only $15 \%$ in the South of Italy.

The composition of the inflow of migrants has changed over time due both to easy access favored by the strategic position in the Mediterranean area, and to the absence of established immigration policies deriving from past relevant colonial experience or agreements with other countries (Del Boca and Venturini 2005). Initially the inflows came mainly from the neighbouring Mediterranean countries, for instance Morocco, Tunisia or from countries with previous ties to Italy such as Latin American countries. This was followed in the 90's by inflows of migrants from countries of the Eastern block (Albania, Poland, Ukraine and Romania) and since 2000 by immigrants from Asia, such as China, India, Philippines and Bangladesh. As Table 1 illustrates, the ten largest immigrant communities account for $65 \%$ of the foreign population in Italy and they mainly are from Eastern European, Asian and North African countries, with immigrants from Romania (22,6\%) being the largest group, followed by Albania, Morocco, China and Ukraine.

[Table 1 around here]

In general, the gender composition of immigrants is balanced, but immigrants tend to display lower levels of education and are much younger than nationals are (migration involves mainly people between 18 and 30 years old). Additionally, immigration being a relatively recent phenomenon, most of the foreigners residing in the country are first-generation immigrants, and most of secondgeneration immigrant population is still underage. As for the socio-economic integration, the characteristic of the inflows of immigrants who, in the majority, were regularised after arriving illegally, has created what has been called a 'subordinate integration', resulting in high labour market 
segmentation along ethnic lines, occupational segregation of immigrants in the lowest layers, and very low occupational and social mobility (Venturini and Villosio, 2018). Typically, male immigrants are employed in the agriculture, construction and machinery manufacturing sectors, while female immigrants are sought in markets for domestic services, private care, restaurants and shops.

\section{Data, variables and methods}

The data used in this paper come from a unique survey on Income and Living Conditions conducted by the Italian National Institute of Statistics (ISTAT) in 2011-2012 on a sample of 25,000 individuals from households with foreign people living in Italy to investigate income and living conditions of foreign citizens. ${ }^{4}$ The survey explores several dimensions of individuals' living conditions, including questions on cultural participation. In particular, respondents were asked to report the frequency of participation to a range of low and high-brow cultural and entertainment events, namely sport events, dancing venues, live concerts, cinema and theater. ${ }^{5}$ Answers possibilities were: never; $1-3$ times; 46 times; 7-12 times and more than 12 times in the last twelve months.

While the survey includes also questions on media consumption (TV and Radio) and reading habits (books, magazines and newspapers) we restrict our focus only to participation to events as they are the ones more likely linked to the local cultural offer available for immigrants in the host country, thus ruling out consumption behavior of cultural goods and services that can be produced and shared by the immigrant groups or accessible from the country of origin through other channels.

Table 2 displays, for each activity considered, the distribution of respondents according to the frequency of use, while Figure 1 compares immigrants' participation rates with those of native population obtained for the same period in the standard survey on living conditions and use of time. As shown in Table 2, the distribution of all five cultural activities is in general very skewed with data revealing a large percentage (52\%) of respondents who had not participated in any of those activities during the twelve months prior to the survey (defined in the text as culturally inactives). Going to the cinema is the most popular activity, followed by dancing venues, music concerts and sport events, whereas going to theater is least frequently attended activity. Interestingly, Figure 1 shows that participation of immigrants tends to be lower than those of natives for cinema, theater and sport events but displays similar rates for concerts and dancing venues.

\footnotetext{
${ }^{4}$ The reference population of the survey is 3,432,000 subjects from households residing in Italy with at least one foreign citizen. https://www.istat.it/it/archivio/10825

${ }^{5}$ It is relevant to notice that the one category of cultural participation that is not taken into account in the survey is attendance to museums and art exhibitions.
} 
[Table 2 around here]

[Figure 1 around here]

As for the drivers of cultural participation, we first consider the individual socio-demographic characteristics such as age, gender, marital status, household composition, education and working condition. These are the variables identified in the literature as the most relevant factors shaping cultural consumption.

More specifically, we include dummies for gender, age groups (with respondent under 30 as the reference group) marital status and a having or not children in the household. Educational attainment is captured by dummies referring to Primary, Lower-secondary, Upper-secondary and Tertiary level (Illiterate is the reference group). While household's income is not available due to restrictions to data access, we use occupational status as the main individual socioeconomic characteristic, that is measured through dummies identifying the working condition and profession. ${ }^{6}$

Turning on immigrants' specific characteristics, based on the previous discussion, three variables captures migrants' level of integration. We use Years of Residence, defined as the difference in years between the time of the survey and the year of arrival of the migrants in Italy, to measure the degree of exposure of immigrants in the host society. Proficiency in native population's language is defined as a dummy variable (Difficulty Italian Language) taking the value 1 if the respondent reports difficulties in speaking and understanding Italian language. Additionally, we include the variable Intention to remain, that is a dummy taking the value of 1 if the respondent sees Italy as the final destination of her migration path.

To account for the heterogeneity in immigrants' cultural background we first control for the country (or region) of origin as defined in the survey. A set of dummy variables for each national group are included in the analysis, being Romania the baseline group ${ }^{7}$ (see Table A1 in Appendix for the distribution of immigrant national groups in the survey sample). Alternatively, we use the respondents' reported religious faith (Religion) ${ }^{8}$ and the Linguistic proximity between the immigrants' language at the country of origin with the Italian language, following the measure proposed by Melitz

\footnotetext{
${ }^{6}$ The dummy variables refer to the following 2 digits ISCO categories based on the Italian classification: Managers, Professionals, Technicians, Clerks, Services and sales, Skilled craft and agricultural workers, Plant and machine operators, Elementary occupations. The baseline group is unoccupied individuals.

${ }^{7}$ The others are Poland, Albania, Ukraine, Moldova, Macedonia, Centre Europe, Other Europe, Morocco, Tunisia, Egypt, North Africa, South-Centre Africa, East-Africa, West-Africa, China, Philippines, East-Asia, India, Bangladesh, South-Centre Asia, Ecuador, Peru, South-Centre America, Ecuador.

${ }^{8}$ Religion is expressed by dummies according to the following categories: Muslim, Catholic, Christian Orthodox, Eastern Religions, Other. The baseline group is made by individuals reporting to be Atheist.
} 
and Toubal (2014). ${ }^{9}$ To account for religiosity as a culture-related practice we also include in all specifications a dummy variable scoring one if the respondent visits at least once in a week a place of worship (Religiosity).

In addition to individual characteristics, to account for geographic variation in the cultural supply and accessibility to cultural goods, we control for city size and the geographical area of residence. More specifically, based on the official national statistics categories, we include dummy variables taking the value of 1 in case the individual lives either in a municipality with less or more than 10,000 inhabitants, while the reference group are respondents living in a Metropolitan $\operatorname{area}^{10}$. Geographical area of residence is defined with dummies for macro-regions, namely North-East, Centre and South (North-West is the reference group). Table A2 in the Appendix reports the descriptive statistics.

In our empirical analysis, we use Probit estimation as preferred strategy to determine the individual propensity for participation in the distinct cultural activities. The dependent variables are defined as dummy variables equal to 1 in case the individual has engaged at least once in the last twelve months in any of the five activities. Moreover, to partly address the diversity in consumption of cultural activities, we analyze the effect of the covariates on a additional dichotomous dependent variable expressing cultural "inactivity", which takes the value of 1 if the respondent does not engage in any of the five activities considered.

The preference for a dichotomous choice model is justified by the large percentage of respondents who have not engaged in cultural activities, making the investigation of the factors influencing the participation/non participation decision the most relevant analytical perspective. Alternatively, the discrete ordered nature of the cultural participation variables available in the survey allows for order probit and zero-inflated ordered probit (ZIOP) model, the latter having been recently applied to study participation to various types of cultural and leisure activities, such as sports (Downward et al., 2014), videogame playing (Borowiecki and Prieto-Rodriguez, 2015) and engagement with tangible and intangible heritage (Ateca-Amestoy et al. 2019). Zero-inflated ordered probit is particularly useful to account for excessive zero observations (as in our case) but also to differentiate between genuine 'non-participants' and individuals who might express an interest, but

\footnotetext{
${ }^{9}$ Using linguistic proximity in our context has two main implications. First, relatively to national group and religion dummies, it provides a quantitative measure of distance between the migrant culture and that of the destination country. Secondly, since some nationalities are grouped into broader categories (in particular for immigrants from Western Europe and sub-Saharan Africa), the linguistic proximity cannot be calculated, being based on the country of origin. For this reason, the sample studied in this specification is more restricted, but it reflects the population of the main immigrant groups, mostly ruling out western European citizens living in Italy, a group that tend to exhibit different social and economic integration patterns in the Italian society.

${ }^{10}$ In Italy the Metropolitan Areas are Roma, Torino, Milano, Venezia, Genova, Bologna, Firenze, Bari, Napoli, Reggio Calabria, Cagliari, Catania, Messina and Palermo.
} 
did not participate due to various constraints (Harris and Zhao, 2007). For robustness, we also estimate the propensity for participation in the cultural activities using the ZIOP model.

\section{Econometric analysis}

In this section, we analyse the determinants influencing the propensity of immigrants to engage or not in the five cultural participation variables as well as the probability of being culturally inactive along all the five cultural dimensions. We first interpret the results concerning individual sociodemographic characteristics and the variables capturing the level of migrants' integration in the host society. Secondly, we discuss whether and how heterogeneity in immigrants' cultural background and distance with the culture of the host society influence cultural participation based on estimates using nationality, religion and linguistic proximity.

\subsection{Effects of sociodemographic characteristics and level of integration}

Table 3 display the marginal effects of the probit model, controlling for immigrants' nationality dummies to capture variation in cultural participation due to unobserved differences across national groups.

[Table 3 around here]

Starting from standard socio-demographic characteristics, except for few factors, the effect of the covariates is generally in line with the findings obtained in other empirical studies on cultural participation. Looking at the five activities considered (Regressions 1-5) gender differences play a role in shaping the propensity to engage in different cultural practices. Female immigrants are more likely to attend theatre and cinemas, while are less likely to attend sports events. Being married and having children has in general a negative effect on the consumption of cultural goods (and a positive one on being culturally inactive), suggesting a time constraint that reduces time available for leisure. As expected, a higher individual's educational attainment is positively associated with cultural participation, but without a clear-cut distinction between highbrow and lowbrow cultural activities. There is a positive and increasing effect of the level of education for cinema, sports events and highbrow cultural activities, such as theatre and music concerts. Conversely, the level of education has a non-significant effect for attendance to dancing venues.

While cultural participation is in general considered to increase or to have a non-linear relationship with age depending on the type of activities, our results for the immigrant population systematically indicate a clear and stable pattern for both highbrow and lowbrow cultural consumption. Holding all other variables at their mean, all age groups over 30 years exhibit significant and negative marginal 
effects compared to immigrants under 30. Moreover, the size of the effect is in many cases larger than that of education, considered as one of the strongest predictors of cultural participation (van Hek and Kraaykamp, 2013). This result might be partly explained considering that, unlike previous evidence (Notten et al., 2015), educational stratification is less indicative of social status of firstgeneration migrants in Italy and, at the same time, age is a better proxy for cognitive abilities associated to cultural consumption rather than the level of education.

The role of labour market and occupational status on cultural consumption is various and follows a non-linear relationship due to the interplay of different factors proxied by this covariate. Having a job and the type of occupation might signal an individual's intellectual capital and lifestyle, proxies household's expenditure capacity for cultural activities and the availability of leisure time. When controlling for the other socioeconomic and demographic factors in play, individuals with occupation of higher status (from professionals to clerks) are significantly more likely to go to cinemas, theaters and concerts (and less likely to be culturally inactive), with a marginal effect that increases (decreases for inactive) the higher the occupational category. For example, professionals are $27 \%$ points more likely to attend concerts (baseline group) and 30\% points less likely to be culturally inactive respect to unoccupied individuals, while for technicians the effect on the same cultural consumption variables are $10 \%$ and $12 \%$ points, respectively. Conversely, lower occupational categories (such as skilled craft and agricultural workers, plant and machine operators and elementary occupations) display a statistically significant but negative marginal effect relatively to unoccupied individuals for almost all the cultural activities considered, either highbrow or lowbrow. This latter finding suggests that the lower the occupational status the higher the relative importance of the time constraint for leisure activities increases.

Finally, the regional and city dimension are supposed to control for variation in the accessibility and opportunities to of cultural goods which can condition the cultural participation of the migrants. In this case, while we don't find a regularity in the effect across macro-regional levels, dummies for the city dimension confirm an urban-rural divide in cultural consumption patterns. Using metropolitan areas as a baseline, the marginal effects of the dummies for medium (more than 10.000 habitants) and small cities (less than 10.000 habitants) display in all cases a negative and significant value.

Turning on the more specific covariates related to immigrants' profile, a first noteworthy finding is that the duration of stay in the destination country (measured by Years since migration) significantly and positively affects the propensity toward cultural participation. In particular, holding all the other covariates at their mean, any additional year of permanence in the host country leads to a marginal effect ranging from $0.22 \%$ (Theatre attendance) to 0.8 percent (Cinema). Both difficulty with Italian language and expressing the intention to remain and settle in Italy as final destination display the 
expected sign, with sizable marginal effects in many cases, always significant at $1 \%$. In particular, difficulty in understanding Italian language has a strongly negative association with an immigrant's participation to cultural activities. For example, this factor reduces of about $20 \%$ points the probability of going to the cinema, $10 \%$ points the probability for dancing venues and $8 \%$ for attending concerts. Conversely, holding other variables at their mean, intention to remain in the host country increases the propensity for cultural participation in a range between $2 \%$ and $8 \%$ points. These results, though expected, are particularly relevant as they provide a first indication in the cultural participation domain of the assimilation and acculturation hypothesis previously identified in the analysis of socio-economic integration process of immigrants. Moreover, except for attending dancing venues, immigrants' frequency of visitation to place of worship is positively associated with cultural participation, suggesting a socialization channel of religious services rather than a substitution effect between secular and religious activities during the leisure time. All the main findings previously described hold also when we use as dependent variable the binary index indicating whether the respondent is inactive over all the five previous participation variables (Reg.6), with marginal effects displaying as expected the opposite sign compared to the previous settings.

For robustness, we also estimate the propensity for participation in the cultural activities using the ZIOP model. While decomposing the decision process between participation and level of attendance add complexity in the interpretation of the findings, the results shows that total marginal effects on the probability of non-attendance outcome are in line with those of dichotomous choice models both for statistical significance and size (See Table A3 in the Appendix for an illustration).

\subsection{Effects of migrants' cultural heterogeneity}

To explain variation in cultural participation rates, the second mechanism we investigate concerns cultural heterogeneity of immigrant communities and their proximity with the host society's culture.

In the previous empirical specification (Table 3) we used dummies for immigrants' country (or region) of origin, which represents a first proxy of migrants' cultural identity. Figure 2 presents the predicted probabilities of engaging in each type of cultural activity (or being culturally inactive) across the main migrants' group. Alternatively, we consider migrants' religion and linguistic proximity with the Italian language. Table 4 displays the marginal effects for these variables, when included separately in the estimation models as an alternative to the national group dummies (see Table A4 and A5 in the appendix for the complete estimates ${ }^{11}$ ).

\footnotetext{
${ }^{11}$ Interestingly, except for religiosity, the effect of all individual sociodemographic characteristics and of the factors explaining the level of integration hold when we consider in alternative empirical specifications either migrants' religion or linguistic proximity of the immigrants' language at the country of origin with the Italian language.
} 
Starting from migrants' nationality, although the marginal effects are not always significant relatively to the baseline group (Romania), Figure 2 clearly points out that, after controlling for all the individual characteristics and migrants' level of integration, marked differences remain across national groups in the probability to engage in all cultural activities or being inactive. We observe a relatively stable pattern in the distribution of the propensity for cultural participation, with migrants from China, India, Bangladesh and frequently Arab countries at the bottom while migrants from Eastern Europe and Latin America always displaying a higher propensity. The distribution across nationalities follows, as expected, a reverse pattern for inactive cultural consumption. Further, the difference between the predicted probabilities explained by migrants' nationality can be very large, with a maximum of $30 \%$ for cinema attendance between the highest scoring group (Ecuador) and the lowest scoring one (Bangladesh).

[Figure 2 around here]

Similarly, we find nearly stable effects when considering other cultural dimensions, namely religion and linguistic proximity (Table 4). The marginal effect on the propensity to engage in all the cultural activities is statistically significant and negative for Muslims and migrants following Eastern religions relatively to those who report to be atheist. In turn, being catholic has a positive impact only for cinema and dancing venues attendance. As for linguistic proximity, this cultural dimension positively influences attendance to Sport events, Dancing venues, Cinema, and it is negatively associated to being inactive. Yet, no significant effect emerges for highbrow cultural activities such as music concerts and theatre.

[Table 4 around here]

These findings provide an indication of the role of migrants' cultural background in the choice to engage in leisure and cultural activities in the host society, but a full interpretation of the effect remain in some cases puzzling. On the one hand, systematic low probabilities (or high probabilities for culturally inactives) of migrants from Asian and Arab countries may reflect the relatively large distance in cultural preferences and habits between those national groups and that of the host society for the type of leisure activities analysed. This result seems also consistent with the effect displayed by the religious and linguistic proximity dimension. In the first case, there is a clear overlapping between the national groups and individuals following religious traditions that are widespread in the same geographic areas (Muslims and Eastern religions). At the same time, Asian and Arab migrants' 
native languages tend to be relatively more distant from Italian language respect to Latin American and Eastern European migrants. On the other hand, the relatively persistent average score across all the cultural activities displayed by Romanian or Albanian migrants (two of the most culturally proximate communities) suggests that differences in behaviour remain attributable to unobserved cultural traits and preferences of the distinct migrant communities. This can be also the reason why, compared to cultural group dummies, the quantitative variable of linguistic proximity explains in a statistically significant way the engagement in only a limited number of cultural activities. To account for such unobserved heterogeneity, one could argue that immigrants could be more likely to engage in certain cultural activities the closer these are to their cultural habits and therefore practiced at their country of origin. However, the potential of such an analytical approach is currently limited by the difficulty of having updated and comparable international statistics on cultural participation for population samples of countries representing the diversity of migrants' national groups in Italy. ${ }^{12}$

Finally, as nationality dummies implicitly capture the size of an immigrant community, this allows testing in the Italian context whether enclave effects are positively associated with migrant consumption of the selected cultural activities, whereby members of larger ethnic minorities might have incentives to produce and consume cultural products within the community. Intuitively, for example, a larger migrant community might be more likely to organize sport events matching its members' tastes, regardless the supply of sport events available for the host society audience. Yet, the relatively persistent low or average score across all the cultural activities displayed by some of the largest communities (i.e. Romanian, Chinese), rules out the hypothesis that the size of the community could be currently a predictor of cultural consumption for first-generation migrants in Italy.

\section{Concluding remarks}

Using unique data from an Italian survey, the paper documents the determinants of cultural participation of immigrants in the host country. With the growing attention in the academic and policy debate to the immigration phenomenon, understanding how immigrant communities have access to and behave in cultural markets helps disentangling an additional dimension of the complex process of immigrants' socio-economic integration, that in turn has usually been confined to labour market and more general social conditions.

\footnotetext{
${ }^{12}$ For example, the International Social Survey Program has conducted only one survey in 2007 on leisure time and sports covering only 33 countries all over the world. For European countries, Eurobarometer has published a cultural participation survey only on 2013.
} 
Our findings indicate that, even after controlling for individual characteristics usually used to explain cultural participation, immigrants' level of integration and cultural background play a role in explaining differences in cultural consumption. Cultural participation is significantly and primary driven by different dimensions of integration in the host country, namely the duration of stay, the reported intention to remain in the country and the knowledge of the Italian language. Notably, being an individual from Latin-American and eastern European countries leads to a higher propensity to engage in cultural activities, whereas immigrants with more distant cultural traits relatively to the Italian culture (such as from Asian and Arab countries) are the least active in cultural participation. As this article represents one of the first attempts to address immigrants' cultural consumption and its determinants, much more theoretical and empirical work is needed. In line with the literature on the effect of migrants' integration on economic and social outcomes in the host society, our results shed lights on a positive association between the level of integration and the propensity to access various types of cultural activities and confirm the fact that cultural differences still matter in explaining variation in cultural participation. Yet, the use of cross-sectional data does not enable to fully unveil the causal nexus between specific factors related to migrants' level of integration and different types of cultural consumption in the host society. At the same, the complex effect of migrants' cultural background that varies across cultural group and depending on the type of cultural activities considered suggests the need for more in-depth studies on individual cultural activities with better data on the preferences and cultural tastes of distinct immigrant communities.

Finally, it is worth noticing that migratory phenomena tend to be highly context-specific, depending on both the social, cultural and institutional characteristics of the migration flows as well as of the destination country. This implies that the evidence portrayed for the Italian case could not be so easily generalized and therefore empirical studies applied to other contexts are required to spur comparative research. 


\section{References}

Adsera, A., \& Pytlikova, M. (2015). The role of language in shaping international migration. The Economic Journal, 125(586), F49-F81.

Algan, Y., Bisin, A., Manning, A., \& Verdier, T. (2013). Cultural integration of immigrants in Europe (p. 359). Oxford University Press

Ateca-Amestoy, V. (2008). Determining heterogeneous behavior for theatre attendance. Journal of Cultural Economics, 32(2), 127-151.

Ateca-Amestoy, V., Gorostiaga, A., \& Rossi, M. (2019). Motivations and barriers to heritage engagement in Latin America: tangible and intangible dimensions. Journal of Cultural Economics, 1-27.

Belot, M., \& Ederveen, S. (2012). Cultural barriers in migration between OECD countries. Journal of Population Economics, 25(3), 1077-1105.

Bisin, A., Patacchini, E., Verdier, T. \& Y. Zenou (2008). Are Muslims immigrants different in terms of cultural integration? Journal of the European Economic Association 6, 445-456.

Bisin, A., Patacchini, E., Verdier, T., \& Zenou, Y. (2016). Bend it like Beckham: Ethnic identity and integration. European Economic Review, 90, 146-164.

Borjas, G. J. (1995). Assimilation and Changes in Cohort Quality Revisited: What Happened to Immigration Earnings in the 1980s? Journal of Labor Economics. 13(2), 201-245.

Borowiecki, K. J., \& Prieto-Rodriguez, J. (2015). Video games playing: A substitute for cultural consumption?. Journal of Cultural Economics, 39(3), 239-258.

Chiswick, B. R. (1978). The effect of Americanization on the earnings of foreign-born men. Journal of Political Economy, 86(5), 897-921.

Chiswick B.R. (1991) Reading, speaking, and earnings among low-skilled immigrants. Journal of Labor Economics 9:149-170

Del Boca, D., Venturini, A. (2005) Italian Migration, in Zimmermann K. (ed), European Migration, Oxford University Press, 303-336.

Desmet, K., Ortuño-Ortín, I., \& Wacziarg, R. (2017). Culture, ethnicity, and diversity. American Economic Review, 107(9), 2479-2513.

De Palo, D., Faini, R., \& Venturini, A. (2007). The Social Assimilation of Immigrants. The World Bank Social Protection DP 0701.

Diehl, C., Lubbers, M., Muhlau, P. \& Platt, L. (2016). Starting out: New Migrants' Socio-Cultural Integration Trajectories in Four European Destinations. Ethnicities 16 (2).

Downward, P., Lera-Lopez, F., \& Rasciute, S. (2011). The zero-inflated ordered probit approach to modelling sports participation. Economic Modelling, 28(6), 2469-2477.

Dustmann, Ch. (1996). The Social Assimilation of Immigrants. Journal of Population Economics. 9 , 37-54.

Dustmann, C., \& Fabbri, F. (2003). Language proficiency and labour market performance of immigrants in the UK. The Economic Journal, 113(489), 695-717.

Falk, M., \& Katz-Gerro, T. (2016). Cultural participation in Europe: Can we identify common determinants?. Journal of Cultural Economics, 40(2), 127-162.

Gray, C. M. (2003). Participation. A handbook of cultural economics, 356.

Harris, M. N., \& Zhao, X. (2007). “A zero-inflated ordered probit model, with an application to modelling tobacco consumption”. Journal of Econometrics, 141(2), 1073-1099 
Katz-Gerro, T., Raz, S., \& Yaish, M. (2009). How do class, status, ethnicity, and religiosity shape cultural omnivorousness in Israel?. Journal of Cultural Economics, 33(1), 1-17.

Katz-Gerro, T., \& Meier Jaeger, M. (2012). Religion, religiosity, and cultural stratification: theoretical links and empirical evidence. In Religion, work and inequality (pp. 337-366). Emerald Group Publishing Limited.

Lazear, E. P. (1999). Culture and language. Journal of political Economy, 107(S6), S95-S126.

Levine, L. W. (1988). Highbrow/Lowbrow: the emergence of cultural hierarchy in America. Harvard University Press.

Melitz, J., \& Toubal, F. (2014). Native language, spoken language, translation and trade. Journal of International Economics, 93(2), 351-363.

Notten, N., Lancee, B., van de Werfhorst, H. G., \& Ganzeboom, H. B. (2015). Educational stratification in cultural participation: cognitive competence or status motivation?. Journal of Cultural Economics, 39(2), 177-203.

Novak-Leonard, J. (2015). Immigrants, Arts Participation, and the Shifting Cultural Landscape in the US: An Empirical Analysis. University of Chicago Cultural Policy Center, Working Paper August 2015

OECD (2014). Jobs for Immigrants (Vol. 4). Labour Market Integration in Italy. Paris: OECD Publishing.

Peterson, R.A. (2005). Problems in comparative research: the example of omnivorousness. Poetics, 33(5-6): 257-82.

Reyneri, E. (2007). Immigration in Italy: Trends and perspectives. Argo: Iom.

Seaman, B. (2006), 'Empirical studies of demand for the performing arts', in Ginsburgh, V., and Throsby, D., eds, Handbook of the Economics of Art and Culture, Elsevier, Amsterdam, pp 415472.

Schulze, G. G. (1999). International trade in art. Journal of Cultural Economics, 23(1-2), 109-136.

Stigler, G.J. and G.S. Becker (1977), 'De Gustibus Non Est Disputandum', American Economic Review, 67, 1 (March), 76-90.

United Nations, Department of Economic and Social Affairs, Population Division (2016). International Migration Report 2015 (ST/ESA/SER.A/384)

Van Eijck, K. (2011). The impact of religious identity and social orientations on visual arts appreciation. European Sociological Review, 28(3), 394-407.

Van Wel, F., Couwenbergh-Soeterboek, N., Couwenbergh, C., Ter Bogt, T., \& Raaijmakers, Q. (2006). Ethnicity, youth cultural participation, and cultural reproduction in the Netherlands. Poetics, 34(1), 65-82.

Venturini A., 2004, Migration in Europe 1950-2000, CUP, New York

Venturini, A., \& Villosio, C. (2018). Are migrants an asset in recession? Insights from Italy. Journal of Ethnic and Migration Studies, 44(14), 2340-2357

van Hek, M., \& Kraaykamp, G. (2013). Cultural consumption across countries: A multi-level analysis of social inequality in highbrow culture in Europe. Poetics, 41(4), 323-341.

Yaish, M., \& Katz-Gerro, T. (2010). Disentangling 'cultural capital': The consequences of cultural and economic resources for taste and participation. European Sociological Review, 28(2), 169185. 


\section{TABLES}

Table 1: Foreign residents in Italy by nationality, 2015

\begin{tabular}{lcc}
\hline Nationality & Population & \% \\
\hline Romania & 1.131 .839 & $22,6 \%$ \\
Albania & 490.483 & $9,8 \%$ \\
Morocco & 449.058 & $9,0 \%$ \\
China & 265.820 & $5,3 \%$ \\
Ukraine & 226.060 & $4,5 \%$ \\
Philippines & 168.238 & $3,4 \%$ \\
India & 147.815 & $2,9 \%$ \\
Moldova & 147.388 & $2,9 \%$ \\
Bangladesh & 115.301 & $2,3 \%$ \\
Peru & 109.668 & $2,2 \%$ \\
Other & 1.558 .496 & $35,2 \%$ \\
Total & 5.014 .437 & $100,0 \%$ \\
\hline
\end{tabular}


Table 2 - Frequency of attendance per cultural activities (percent per category)

Frequency

Never 1-3 times 4-6 times 7-12 times 13+ times

\begin{tabular}{lccccc}
\hline Sport events & 81.78 & 11.96 & 3.37 & 1.44 & 1.45 \\
Dancing venues & 80.93 & 9.67 & 4.36 & 2.56 & 2.48 \\
Cinema & 63.94 & 20.35 & 9.41 & 3.75 & 2.54 \\
Concerts & 81.49 & 13.60 & 3.21 & 1.10 & 0.60 \\
Theater & 88.59 & 9.48 & 1.23 & 0.43 & 0.27 \\
\hline
\end{tabular}


$\underline{\text { Table } 3 \text { - Probit estimation for immigrants' cultural participation, marginal effects displayed }}$

\begin{tabular}{|c|c|c|c|c|c|c|}
\hline & $\begin{array}{c}\text { (1) } \\
\text { Sport events }\end{array}$ & $\begin{array}{c}(2) \\
\text { Dancing venues }\end{array}$ & $\begin{array}{c}\text { (3) } \\
\text { Cinema }\end{array}$ & $\begin{array}{c}(4) \\
\text { Concerts }\end{array}$ & $\begin{array}{c}\text { (5) } \\
\text { Theatre }\end{array}$ & $\begin{array}{c}\text { (6) } \\
\text { Culturally } \\
\text { Inactive } \\
\end{array}$ \\
\hline Years of migration & $0.00333 * * *$ & 0.0029 & $0.00854 * * *$ & $0.00406 * * *$ & $\begin{array}{c}0.00226 * * * \\
(0.000404)\end{array}$ & $\begin{array}{c}-0.00809^{* * * *} \\
(0.000914)\end{array}$ \\
\hline Difficulty italian language & $\begin{array}{c}(0.000608) \\
-0.0759 * * * \\
(0.0115)\end{array}$ & $\begin{array}{c}(0.000674) \\
-0.104 * * * \\
(0.0127)\end{array}$ & $\begin{array}{c}(0.000849) \\
-0.207 * * * \\
(0.0159)\end{array}$ & $\begin{array}{c}(0.000648) \\
-0.0881 * * * \\
(0.0121)\end{array}$ & $\begin{array}{r}(0.000 \\
-0.036 \\
(0.00\end{array}$ & $\begin{array}{c}(0.000914) \\
0.213 * * * \\
(0.0156)\end{array}$ \\
\hline Intention to remain & $\begin{array}{c}0.0303 * * * \\
(0.00668)\end{array}$ & $\begin{array}{c}0.0370 * * * \\
(0.00714)\end{array}$ & $\begin{array}{c}0.0860 * * * \\
(0.00911)\end{array}$ & $\begin{array}{c}0.0282 * * * \\
(0.00707)\end{array}$ & $\begin{array}{c}0.0260 * * * \\
(0.00469)\end{array}$ & $\begin{array}{c}-0.0777 * * * \\
(0.00977)\end{array}$ \\
\hline Religiosity & $\begin{array}{c}0.0307 * * * \\
(0.00693)\end{array}$ & $\begin{array}{l}-0.00835 \\
(0.00760)\end{array}$ & $\begin{array}{l}0.0200 * * \\
(0.00959)\end{array}$ & $\begin{array}{l}0.0168 * * \\
(0.00740)\end{array}$ & $\begin{array}{c}0.0188 * * * \\
(0.00465)\end{array}$ & $\begin{array}{c}-0.0212 * * \\
(0.0104)\end{array}$ \\
\hline Female & $\begin{array}{c}-0.0991 * * * \\
(0.00693)\end{array}$ & $\begin{array}{c}0.00371 \\
(0.00759)\end{array}$ & $\begin{array}{c}0.0399 * * * \\
(0.00977)\end{array}$ & $\begin{array}{l}0.000123 \\
(0.00748)\end{array}$ & $\begin{array}{c}0.0252 * * * \\
(0.00484)\end{array}$ & $\begin{array}{c}-0.00298 \\
(0.0107)\end{array}$ \\
\hline Age 30-39 & $\begin{array}{c}-0.0296 * * * \\
(0.00957)\end{array}$ & $\begin{array}{c}-0.0971 * * * \\
(0.0108)\end{array}$ & $\begin{array}{c}-0.119^{* * * *} \\
(0.0126)\end{array}$ & $\begin{array}{r}-0.032 \\
(0.00\end{array}$ & $\begin{array}{l}-0.00896 \\
(0.00636)\end{array}$ & $\begin{array}{c}0.102 * * * \\
(0.0127)\end{array}$ \\
\hline Age $40-49$ & $\begin{array}{c}-0.0498 * * * \\
(0.0105)\end{array}$ & $\begin{array}{c}-0.139 * * * \\
(0.0116)\end{array}$ & $\begin{array}{c}-0.198 * * * \\
(0.0136)\end{array}$ & $\begin{array}{c}-0.0557 * * * \\
(0.0109)\end{array}$ & $\begin{array}{c}-0.0127 \\
(0.00704)\end{array}$ & $\begin{array}{c}0.183 * * * \\
(0.0141)\end{array}$ \\
\hline Age $>49$ & $\begin{array}{r}-0.11 \\
(0.01\end{array}$ & $\begin{array}{r}-0.21 \\
(0.01\end{array}$ & $\begin{array}{c}-0.299 * * * \\
(0.0133)\end{array}$ & $\begin{array}{r}-0.10 \\
(0.0\end{array}$ & $\begin{array}{c}-0.0212 * * * \\
(0.00719)\end{array}$ & $\begin{array}{c}0.313^{* * * *} \\
(0.0148)\end{array}$ \\
\hline Married & $\begin{array}{c}-0.0231 * * * \\
(0.00711)\end{array}$ & $\begin{array}{c}-0.0820 * * * \\
(0.00751)\end{array}$ & $\begin{array}{c}-0.0477 * * * \\
(0.00959)\end{array}$ & $\begin{array}{r}-0.044 \\
(0.00\end{array}$ & $\begin{array}{c}-0.0146 * * * \\
(0.00479)\end{array}$ & $\begin{array}{c}0.0791 * * * \\
(0.0104)\end{array}$ \\
\hline Children & $\begin{array}{r}-0.067 \\
(0.007\end{array}$ & $\begin{array}{l}-0.14 \\
(0.00\end{array}$ & $\begin{array}{l}-0.162 * * * \\
(0.00999)\end{array}$ & $\begin{array}{r}-0.09 \\
(0.0\end{array}$ & $\begin{array}{r}-0.02 \\
(0.0\end{array}$ & $\begin{array}{c}0.172 * * * \\
(0.0110)\end{array}$ \\
\hline Primary education & $\begin{array}{l}0.00563 \\
(0.0140)\end{array}$ & $\begin{array}{l}-0.0 \\
(0.01\end{array}$ & $\begin{array}{c}0.0238 \\
(0.0211)\end{array}$ & $\begin{array}{l}0.00431 \\
(0.0151)\end{array}$ & $\begin{array}{c}0.0214 * * \\
(0.0103)\end{array}$ & $\begin{array}{l}-0.0257 \\
(0.0233)\end{array}$ \\
\hline education & $\begin{array}{r}0.037 \\
(0.0\end{array}$ & $\begin{array}{l}-0.0 \\
(0.0\end{array}$ & $\begin{array}{r}0.052 \\
(0.0\end{array}$ & $\begin{array}{r}0 . \\
(0 .\end{array}$ & $\begin{array}{l}0.020 \\
(0.00\end{array}$ & $\begin{array}{c}-0.0481 * * * \\
(0.0179)\end{array}$ \\
\hline Upper & $\begin{array}{r}0.059 \\
(0.01\end{array}$ & $\begin{array}{r}0.01 \\
(0.01\end{array}$ & $\begin{array}{l}0.10 \\
(0.1\end{array}$ & $\begin{array}{r}0.06 \\
(0.0\end{array}$ & $\begin{array}{r}0.026 \\
(0.06\end{array}$ & $\begin{array}{c}-0.108^{* * *} \\
(0.0178)\end{array}$ \\
\hline Tertiar & $\begin{array}{c}0.0788 * * * * \\
(0.0150)\end{array}$ & & & $\begin{array}{l}0.1 \\
(0.1\end{array}$ & $\begin{array}{c}0.0733 * * * \\
(0.0109)\end{array}$ & $\begin{array}{c}-0.176^{* * * *} \\
(0.0222)\end{array}$ \\
\hline Managers & $\begin{array}{c}-0.00598 \\
(0.0381)\end{array}$ & $\begin{array}{c}0.0622 \\
(0.0465)\end{array}$ & $\begin{array}{c}0.0856 \\
(0.0555)\end{array}$ & $\begin{array}{l}0.00323 \\
(0.0400)\end{array}$ & $\begin{array}{c}0.0652 \\
(0.0366)\end{array}$ & $\begin{array}{l}-0.0975 \\
(0.0570)\end{array}$ \\
\hline Professionals & $\begin{array}{c}0.0444 \\
(0.0295)\end{array}$ & $\begin{array}{c}0.0456 \\
(0.0297)\end{array}$ & $\begin{array}{c}0.221 * * * \\
(0.0404)\end{array}$ & $\begin{array}{c}0.273 * * * \\
(0.0386)\end{array}$ & $\begin{array}{c}0.145^{* * *} \\
(0.0297)\end{array}$ & $\begin{array}{c}-0.305^{* * * *} \\
(0.0379)\end{array}$ \\
\hline Technicians & $\begin{array}{c}-0.00482 \\
(0.0206)\end{array}$ & $\begin{array}{c}0.0585 * * \\
(0.0236)\end{array}$ & $\begin{array}{c}0.117 * * * \\
(0.0305)\end{array}$ & $\begin{array}{l}0.100^{* * * *} \\
(0.0252)\end{array}$ & $\begin{array}{c}0.0670^{* * * *} \\
(0.0185)\end{array}$ & $\begin{array}{c}-0.129 * * * \\
(0.0316)\end{array}$ \\
\hline Clerk: & $\begin{array}{c}0.0457 \\
(0.0279)\end{array}$ & $\begin{array}{c}0.0792 * * * \\
(0.0295)\end{array}$ & $\begin{array}{c}0.118 * * * \\
(0.0371)\end{array}$ & $\begin{array}{c}0.0751 * * \\
(0.0297)\end{array}$ & $\begin{array}{c}0.0242 \\
(0.0194)\end{array}$ & $\begin{array}{c}-0.154 * * * \\
(0.0382)\end{array}$ \\
\hline Service & $\begin{array}{c}-0.0161 \\
(0.00956)\end{array}$ & $\begin{array}{c}0.0435 * * * \\
(0.00988)\end{array}$ & $\begin{array}{c}0.0101 \\
(0.0125)\end{array}$ & $\begin{array}{c}0.00501 \\
(0.00963)\end{array}$ & $\begin{array}{l}-0.0130 * * \\
(0.00627)\end{array}$ & $\begin{array}{c}-0.0307 * * \\
(0.0135)\end{array}$ \\
\hline Skilled craft and agriculture & $\begin{array}{c}-0.0458 * * * \\
(0.00940)\end{array}$ & $\begin{array}{r}0.0 \\
(0.0\end{array}$ & $\begin{array}{c}-0.0273 * * \\
(0.0137)\end{array}$ & $\begin{array}{c}-0.0228 * * \\
(0.0103)\end{array}$ & $\begin{array}{c}-0.0282 * * * \\
(0.00680)\end{array}$ & $\begin{array}{l}0.00938 \\
(0.0150)\end{array}$ \\
\hline Plant and machine operators & $\begin{array}{l}-0.00759 \\
(0.0161)\end{array}$ & $\begin{array}{c}0.0577 * * * \\
(0.0193)\end{array}$ & $\begin{array}{c}0.0117 \\
(0.0226)\end{array}$ & $\begin{array}{l}0.00706 \\
(0.0176)\end{array}$ & $\begin{array}{c}-0.0329 * * * \\
(0.0101)\end{array}$ & $\begin{array}{l}-0.0442 \\
(0.0239)\end{array}$ \\
\hline Elemen & $\begin{array}{c}-0.0536 * * * \\
(0.00859)\end{array}$ & $\begin{array}{l}-0.00951 \\
(0.00886)\end{array}$ & $\begin{array}{c}-0.0670 * * * \\
(0.0115)\end{array}$ & $\begin{array}{c}-0.0253 * * * \\
(0.00899)\end{array}$ & $\begin{array}{c}-0.0309 * * * \\
(0.00577)\end{array}$ & $\begin{array}{c}0.0367 * * * * \\
(0.0128)\end{array}$ \\
\hline $\mathrm{N}$ & $\begin{array}{l}0.000784 \\
(0.00989)\end{array}$ & $\begin{array}{c}-0.0383 * * * \\
(0.0108)\end{array}$ & $\begin{array}{c}-0.0415 * * * \\
(0.0141)\end{array}$ & $\begin{array}{c}0.0133 \\
(0.0103)\end{array}$ & $\begin{array}{c}0.00681 \\
(0.00713)\end{array}$ & $\begin{array}{c}0.0236 \\
(0.0151)\end{array}$ \\
\hline Centre & $\begin{array}{c}0.0386^{* * * *} \\
(0.0105)\end{array}$ & $\begin{array}{c}0.0232 * * \\
(0.0116)\end{array}$ & $\begin{array}{c}0.0250 \\
(0.0145)\end{array}$ & $\begin{array}{c}0.0219 * * \\
(0.0105)\end{array}$ & $\begin{array}{c}0.0232 * * * \\
(0.00742)\end{array}$ & $\begin{array}{c}-0.0330^{* *} \\
(0.0152)\end{array}$ \\
\hline
\end{tabular}




\begin{tabular}{lcccccc} 
South & -0.00343 & $-0.0252^{* * *}$ & $-0.0862 * * *$ & $0.0299 * * *$ & $-0.0120 * *$ & $0.0794 * * *$ \\
Municipality < 10,000 & $(0.00857)$ & $(0.00959)$ & $(0.0121)$ & $(0.00897)$ & $(0.00577)$ & $(0.0130)$ \\
& 0.00936 & $-0.0503 * * *$ & $-0.101 * * *$ & 0.00537 & $-0.0235^{* * *}$ & $0.101 * * *$ \\
Municipality > 10,000 & $(0.00883)$ & $(0.00990)$ & $(0.0125)$ & $(0.00970)$ & $(0.00639)$ & $(0.0136)$ \\
& $0.0220 * * *$ & $-0.0323 * * *$ & $-0.0553 * * *$ & 0.00520 & $-0.0184 * * *$ & $0.0573 * * *$ \\
& $(0.00763)$ & $(0.00877)$ & $(0.0110)$ & $(0.00821)$ & $(0.00568)$ & $(0.0117)$ \\
Nationalities & & & & & & \\
& Yes & Yes & Yes & Yes & Yes & Yes \\
Observations & & & & & & \\
Log Pseudo-likelihood & 14,791 & 14,814 & 14,814 & 14,814 & 14,814 & 14,791 \\
Wald & -6117 & -6274 & -7852 & -6515 & -3833 & -8725 \\
Pseudo R2 & 1151 & 2674 & 3179 & 1280 & 1114 & 2986 \\
Stand & 0.0860 & 0.176 & 0.168 & 0.0895 & 0.127 & 0.146 \\
\hline
\end{tabular}

Standard errors in parentheses: $* * * \mathrm{p}<0.01,{ }^{* *} \mathrm{p}<0.05,{ }^{*} \mathrm{p}<0.1$ 
Table 4 -Marginal effects of migrants' religion and linguistic proximity, probit estimation

\begin{tabular}{|c|c|c|c|c|c|c|}
\hline & \multicolumn{6}{|c|}{ Religion (atheist as reference group): } \\
\hline & Sport events & Dancing venues & Cinema & Concerts & Theatre & $\begin{array}{l}\text { Culturally } \\
\text { Inactive }\end{array}$ \\
\hline Muslim & $\begin{array}{c}-0.0429 * * * \\
(0.0138)\end{array}$ & $\begin{array}{c}-0.0889 * * * \\
(0.0150)\end{array}$ & $\begin{array}{c}-0.112 * * * \\
(0.0185)\end{array}$ & $\begin{array}{c}-0.0617 * * * \\
(0.0150)\end{array}$ & $\begin{array}{c}-0.0416 * * * \\
(0.0100)\end{array}$ & $\begin{array}{l}0.113 * * * \\
(0.0202)\end{array}$ \\
\hline Catholic & $\begin{array}{c}0.0202 \\
(0.0144)\end{array}$ & $\begin{array}{l}0.0358 * * \\
(0.0159)\end{array}$ & $\begin{array}{c}0.0594 * * * \\
(0.0192)\end{array}$ & $\begin{array}{l}0.0173 \\
(0.0155)\end{array}$ & $\begin{array}{c}0.0145 \\
(0.0106)\end{array}$ & $\begin{array}{c}-0.0743 * * * \\
(0.0205)\end{array}$ \\
\hline Orthodox & $\begin{array}{l}-0.0146 \\
(0.0139)\end{array}$ & $\begin{array}{l}-0.0190 \\
(0.0152)\end{array}$ & $\begin{array}{l}-0.0180 \\
(0.0186)\end{array}$ & $\begin{array}{c}-0.0336 * * \\
(0.0149)\end{array}$ & $\begin{array}{l}-0.0165 \\
(0.0101)\end{array}$ & $\begin{array}{c}0.0169 \\
(0.0201)\end{array}$ \\
\hline Eastern Religions & $\begin{array}{c}-0.0816 * * * \\
(0.0266)\end{array}$ & $\begin{array}{c}-0.160 * * * \\
(0.0222)\end{array}$ & $\begin{array}{c}-0.233 * * * \\
(0.0333)\end{array}$ & $\begin{array}{c}-0.100 * * * \\
(0.0303)\end{array}$ & $\begin{array}{c}-0.0602 * * * \\
(0.0174)\end{array}$ & $\begin{array}{l}0.240 * * * \\
(0.0437)\end{array}$ \\
\hline Other religion & -0.0121 & $-0.0540 * * *$ & -0.00513 & 0.00652 & 0.00432 & 0.00522 \\
\hline \multirow{5}{*}{$\begin{array}{l}\text { Individual controls } \\
\text { Geographic and city } \\
\text { controls } \\
\text { Observations } \\
\end{array}$} & YES & YES & YES & YES & YES & YES \\
\hline & YES & YES & YES & YES & YES & YES \\
\hline & 13,732 & 13,752 & 13,752 & 13,752 & 13,752 & 13,732 \\
\hline & \multicolumn{6}{|c|}{ Linguistic proximity } \\
\hline & Sport events & Dancing venues & Cinema & Concerts & Theatre & $\begin{array}{l}\text { Culturally } \\
\text { Inactive }\end{array}$ \\
\hline Linguistic proximity & $\begin{array}{c}0.0674 * * * \\
(0.0205)\end{array}$ & $\begin{array}{c}0.103 * * * \\
(0.0219)\end{array}$ & $\begin{array}{c}0.160^{* * * *} \\
(0.0277)\end{array}$ & $\begin{array}{l}-0.00313 \\
(0.0211)\end{array}$ & $\begin{array}{l}0.000839 \\
(0.0132)\end{array}$ & $\begin{array}{c}-0.130^{* * *} \\
(0.0304)\end{array}$ \\
\hline $\begin{array}{l}\text { Sociodemographic and } \\
\text { migrants controls }\end{array}$ & YES & YES & YES & YES & YES & YES \\
\hline $\begin{array}{l}\text { Geographic and city } \\
\text { controls }\end{array}$ & YES & YES & YES & YES & YES & YES \\
\hline Observations & 11,019 & 11,035 & 11,035 & 11,035 & 11,035 & 11,019 \\
\hline
\end{tabular}

Standard errors in parentheses: ${ }^{* * *} \mathrm{p}<0.01,{ }^{* *} \mathrm{p}<0.05,{ }^{*} \mathrm{p}<0.1$ 


\section{FIGURES}

Figure 1 - Participation rates across cultural and leisure activities, native and foreign population

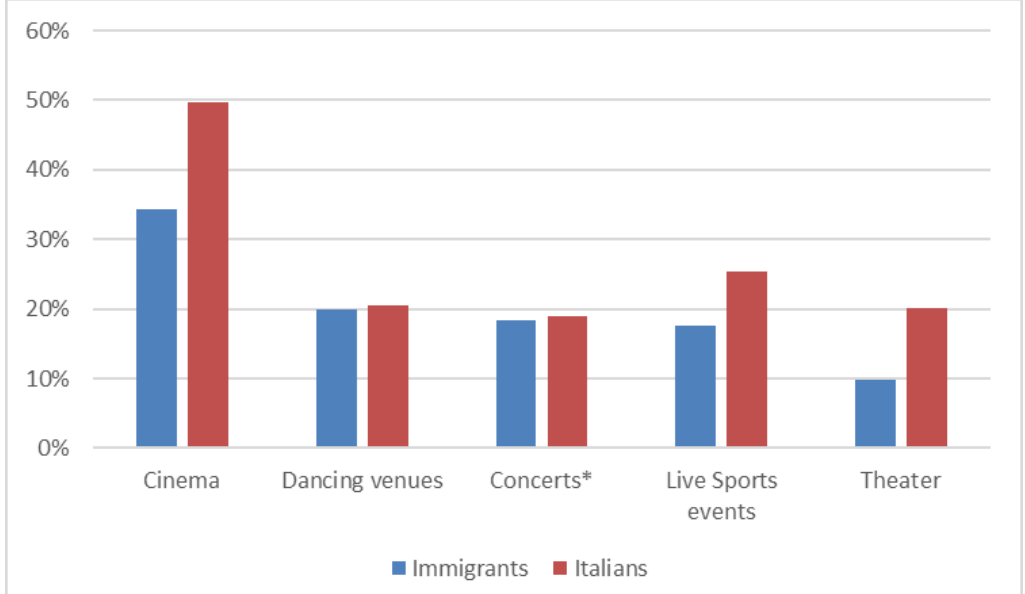

Note: * for native population concerts category does not include classical music performances 
Figure 2 Predicted Probabilities of cultural participation by immigrants' nationality (selected groups)

Fig.2-a

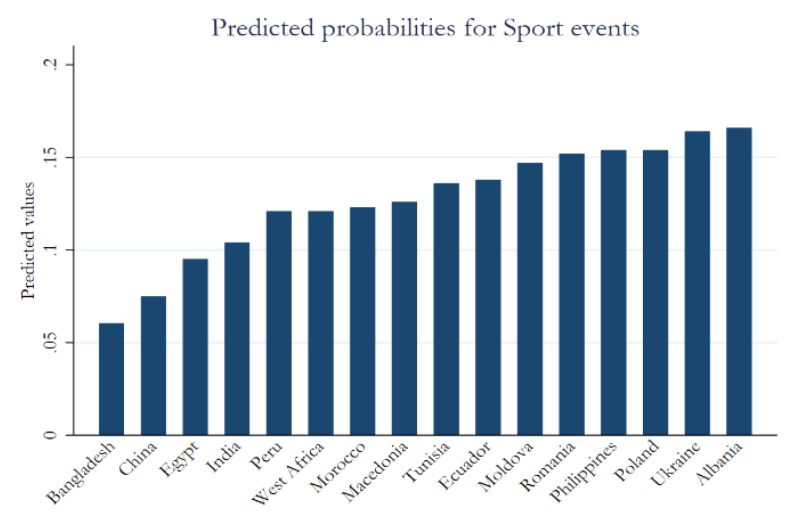

Fig. 2-c

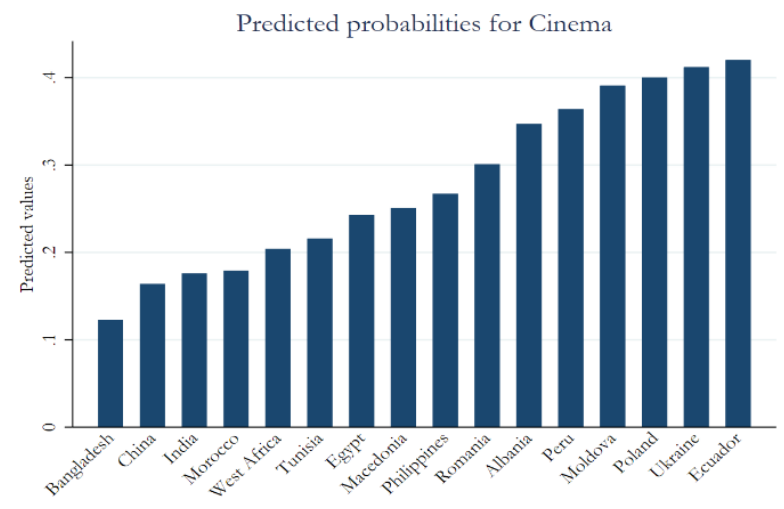

Fig.2-e

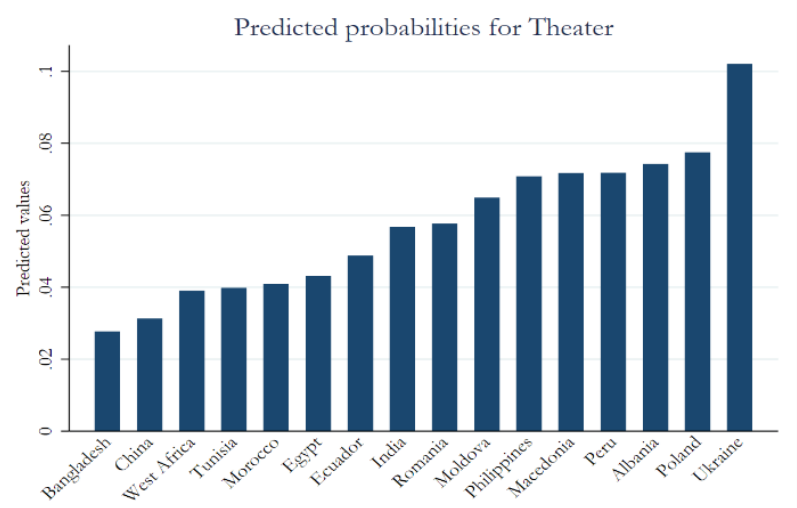

Fig.2-b

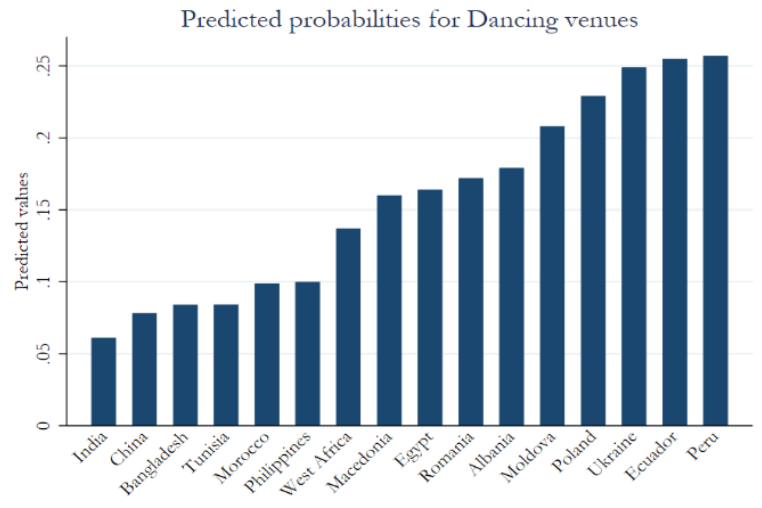

Fig.2-d

Predicted probabilities for Concerts

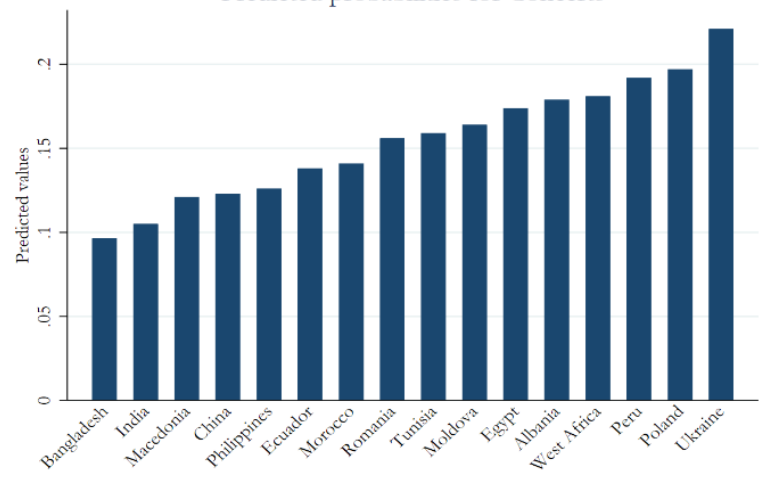

Fig.2-f

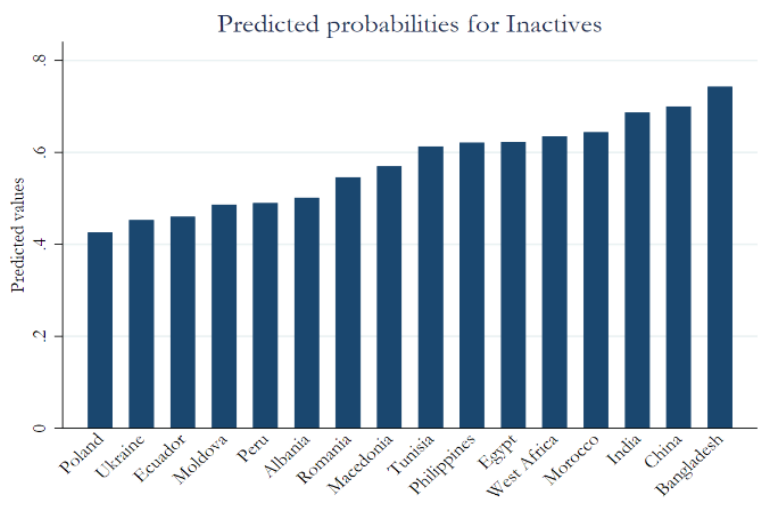


Table A1. Distribution of immigrant national groups in the survey sample

\begin{tabular}{lcc}
\hline Nationality dummies & $\mathrm{N}$ & Mean $(\%)$ \\
\hline Romania & 17,111 & 0,239 \\
Albania & 17,111 & 0,135 \\
Morocco & 17,111 & 0,0964 \\
European Union (other) & 17,111 & 0,0593 \\
Ukraine & 17,111 & 0,0514 \\
West-Africa & 17,111 & 0,042 \\
Centre Europe & 17,111 & 0,0365 \\
South-Centre America & 17,111 & 0,0362 \\
South-Centre Asia & 17,111 & 0,0357 \\
Poland & 17,111 & 0,0356 \\
China & 17,111 & 0,034 \\
Tunisia & 17,111 & 0,0286 \\
Philippines & 17,111 & 0,0267 \\
Moldova & 17,111 & 0,025 \\
India & 17,111 & 0,0191 \\
Macedonia & 17,111 & 0,0185 \\
Ecuador & 17,111 & 0,0163 \\
Bangladesh & 17,111 & 0,0161 \\
Peru & 17,111 & 0,0147 \\
East-Africa & 17,111 & 0,00953 \\
Egypt & 17,111 & 0,00923 \\
North Africa & 17,111 & 0,00695 \\
South-Centre Africa & 17,111 & 0,00356 \\
East-Asia & 17,111 & 0,00327 \\
Other Europe & 17,111 & 0,00117 \\
\hline
\end{tabular}


Table A2. Summary statistics

\begin{tabular}{|c|c|c|c|c|c|}
\hline VARIABLES & $\mathrm{N}$ & $\begin{array}{c}\text { Mean } \\
(\%)\end{array}$ & $\mathrm{sd}$ & $\min$ & $\max$ \\
\hline Sport events & 16,877 & 0.175 & & 0 & 1 \\
\hline Dancing venues & 16,906 & 0.199 & & 0 & 1 \\
\hline Cinema & 16,907 & 0.344 & & 0 & 1 \\
\hline Concerts & 16,905 & 0.184 & & 0 & 1 \\
\hline Theater & 16,905 & 0.097 & & 0 & 1 \\
\hline \multicolumn{5}{|l|}{ Demographics } & 1 \\
\hline Female & 17,111 & 0.557 & & 0 & 1 \\
\hline Married & 17,111 & 0.447 & & 0 & 1 \\
\hline Children & 17,111 & 0.561 & & 0 & 1 \\
\hline \multicolumn{6}{|l|}{ Age classes } \\
\hline Age $<30$ & 17,111 & 0.324 & & 0 & 1 \\
\hline Age $30-39$ & 17,111 & 0.291 & & 0 & 1 \\
\hline Age $40-49$ & 17,111 & 0.227 & & 0 & 1 \\
\hline Age $<49$ & 17,111 & 0.159 & & 0 & 1 \\
\hline \multicolumn{6}{|l|}{ Educational attainment } \\
\hline Illiterate & 16,899 & 0.114 & & 0 & 1 \\
\hline Primary education & 16,899 & 0.092 & & 0 & 1 \\
\hline Low-secondary education & 16,899 & 0.299 & & 0 & 1 \\
\hline Upper-secondary education & 16,899 & 0.398 & & 0 & 1 \\
\hline Tertiary education & 16,899 & 0.096 & & 0 & 1 \\
\hline \multicolumn{6}{|l|}{ Occupation } \\
\hline Managers & 15,185 & 0.0061 & & 0 & 1 \\
\hline Professionals & 15,185 & 0.013 & & 0 & 1 \\
\hline Technicians & 15,185 & 0.0223 & & 0 & 1 \\
\hline Clerks & 15,185 & 0.014 & & 0 & 1 \\
\hline Service and sales & 15,185 & 0.187 & & 0 & 1 \\
\hline Skilled craft and agriculture & 15,185 & 0.155 & & 0 & 1 \\
\hline Plant and machine operators & 15,185 & 0.040 & & 0 & 1 \\
\hline Elementary occupations & 15,185 & 0.213 & & 0 & 1 \\
\hline Unemployed & 15,185 & 0.342 & & 0 & 1 \\
\hline \multicolumn{6}{|l|}{ City size } \\
\hline Metropolitan area & 17,111 & 0.244 & & 0 & 1 \\
\hline Below 10,000 inhabitans & 17,111 & 0.243 & & 0 & 1 \\
\hline Above 10,000 inhabitans & 17,111 & 0.513 & & 0 & 1 \\
\hline \multicolumn{6}{|l|}{ Area of residence } \\
\hline North-West & 17,111 & 0.186 & & 0 & 1 \\
\hline North-East & 17,111 & 0.185 & & 0 & 1 \\
\hline Centre & 17,111 & 0.170 & & 0 & 1 \\
\hline South & 17,111 & 0.458 & & 0 & 1 \\
\hline \multicolumn{6}{|l|}{ Integration factors } \\
\hline Years of migration & 17,111 & 9.987 & 5.691 & 0 & 30 \\
\hline Difficulty italian language & 16,907 & 0.120 & & 0 & 1 \\
\hline Intention to remain & 15,922 & 0.694 & & 0 & 1 \\
\hline \multicolumn{6}{|l|}{ Cultural factors } \\
\hline Religiosity & 16,686 & 0.258 & & 0 & 1 \\
\hline Linguistic proximity & 12,778 & 0.298 & 0.179 & 0.063 & 0.488 \\
\hline Atheist & 15,664 & 0.061 & & 0 & 1 \\
\hline Muslim & 15,664 & 0.289 & & 0 & 1 \\
\hline Catholic & 15,664 & 0.267 & & 0 & 1 \\
\hline Orthodox & 15,664 & 0.267 & & 0 & 1 \\
\hline Eastern Religions & 15,664 & 0.011 & & 0 & 1 \\
\hline Other Religions & 15,664 & 0.048 & & 0 & 1 \\
\hline
\end{tabular}


Table A3 - Zero Inflated Ordered Probit estimation with nationality dummies - Marginal effects of selected variables for observing 0 outomes decomposed between non-participation and zero consumption

\begin{tabular}{|c|c|c|c|c|c|c|c|c|c|}
\hline & Sport Events & Sport Events & Sport Events & $\begin{array}{l}\text { Dancing } \\
\text { venues }\end{array}$ & $\begin{array}{l}\text { Dancing } \\
\text { venues }\end{array}$ & $\begin{array}{l}\text { Dancing } \\
\text { venues }\end{array}$ & Cinema & Cinema & Cinema \\
\hline & $\begin{array}{c}\text { Non-participation } \\
\operatorname{Pr}(r=0)\end{array}$ & $\begin{array}{l}\text { Zero consumption } \\
\operatorname{Pr}(r=1, \tilde{y}=0)\end{array}$ & $\begin{array}{c}\text { Full } \\
\operatorname{Pr}(y=0)\end{array}$ & $\begin{array}{c}\text { Non-participation } \\
\operatorname{Pr}(r=0)\end{array}$ & $\begin{array}{l}\text { Zero consumption } \\
\operatorname{Pr}(r=1, \tilde{y}=0)\end{array}$ & $\begin{array}{c}\text { Full } \\
\operatorname{Pr}(y=0)\end{array}$ & $\begin{array}{c}\text { Non-participation } \\
\operatorname{Pr}(r=0)\end{array}$ & $\begin{array}{l}\text { Zero consumption } \\
\operatorname{Pr}(r=1, \tilde{y}=0)\end{array}$ & $\begin{array}{c}\text { Full } \\
\operatorname{Pr}(y=0)\end{array}$ \\
\hline Years of migration & $\begin{array}{c}0.00346 \\
(0.00216)\end{array}$ & $\begin{array}{c}-0.00688 * * * \\
(0.00226)\end{array}$ & $\begin{array}{c}-0.00342 * * * \\
(0.000605)\end{array}$ & $\begin{array}{c}-0.00665 * * * \\
(0.00226)\end{array}$ & $\begin{array}{c}0.00346 \\
(0.00214)\end{array}$ & $\begin{array}{c}-0.00319 * * * \\
(0.000641)\end{array}$ & $\begin{array}{l}-0.00250 \\
(0.00162)\end{array}$ & $\begin{array}{c}-0.00459 * * * \\
(0.00164)\end{array}$ & $\begin{array}{c}-0.00709 * * * \\
(0.000809)\end{array}$ \\
\hline Difficulty italian language & $\begin{array}{c}0.0111 \\
(0.0524)\end{array}$ & $\begin{array}{c}0.0579 \\
(0.0515)\end{array}$ & $\begin{array}{c}0.0690 * * * \\
(0.0113)\end{array}$ & $\begin{array}{c}0.0236 \\
(0.0478)\end{array}$ & $\begin{array}{c}0.0665 \\
(0.0460)\end{array}$ & $\begin{array}{c}0.0901 * * * \\
(0.0121)\end{array}$ & $\begin{array}{c}0.0501 \\
(0.0265)\end{array}$ & $\begin{array}{l}0.110 * * * \\
(0.0311)\end{array}$ & $\begin{array}{c}0.160 * * * \\
(0.0135)\end{array}$ \\
\hline Intention to remain & $\begin{array}{c}-0.000154 \\
(0.0263)\end{array}$ & $\begin{array}{l}-0.0264 \\
(0.0263)\end{array}$ & $\begin{array}{c}-0.0265 * * * \\
(0.00649)\end{array}$ & $\begin{array}{l}-0.0310 \\
(0.0233)\end{array}$ & $\begin{array}{l}-0.00191 \\
(0.0234)\end{array}$ & $\begin{array}{c}-0.0330 * * * \\
(0.00650)\end{array}$ & $\begin{array}{c}-0.0486 * * * \\
(0.0158)\end{array}$ & $\begin{array}{l}-0.0222 \\
(0.0166)\end{array}$ & $\begin{array}{c}-0.0708 * * * \\
(0.00826)\end{array}$ \\
\hline Religiosity & $\begin{array}{l}-0.0451 \\
(0.0260)\end{array}$ & $\begin{array}{c}0.0136 \\
(0.0260)\end{array}$ & $\begin{array}{c}-0.0315 * * * \\
(0.00668)\end{array}$ & $\begin{array}{c}-0.109 * * * \\
(0.0352)\end{array}$ & $\begin{array}{c}0.113 * * * \\
(0.0312)\end{array}$ & $\begin{array}{c}0.00488 \\
(0.00807)\end{array}$ & $\begin{array}{c}0.0296 \\
(0.0153)\end{array}$ & $\begin{array}{c}-0.0457 * * * \\
(0.0167)\end{array}$ & $\begin{array}{l}-0.0161 * * \\
(0.00813)\end{array}$ \\
\hline Female & $\begin{array}{c}0.0498 \\
(0.0277)\end{array}$ & $\begin{array}{c}0.0435 \\
(0.0274)\end{array}$ & $\begin{array}{c}0.0933 * * * \\
(0.00729)\end{array}$ & $\begin{array}{c}0.0251 \\
(0.0235)\end{array}$ & $\begin{array}{l}-0.0146 \\
(0.0231)\end{array}$ & $\begin{array}{c}0.0105 \\
(0.00691)\end{array}$ & $\begin{array}{l}-0.0117 \\
(0.0156)\end{array}$ & $\begin{array}{l}-0.0174 \\
(0.0164)\end{array}$ & $\begin{array}{c}-0.0291 * * * \\
(0.00774)\end{array}$ \\
\hline Age $30-39$ & $\begin{array}{l}0.212 * * * \\
(0.0450)\end{array}$ & $\begin{array}{c}-0.185 * * * \\
(0.0451)\end{array}$ & $\begin{array}{l}0.0268 * * * \\
(0.00919)\end{array}$ & $\begin{array}{l}0.00548 \\
(0.0267)\end{array}$ & $\begin{array}{c}0.0837 * * * \\
(0.0260)\end{array}$ & $\begin{array}{c}0.0892 * * * \\
(0.00940)\end{array}$ & $\begin{array}{c}0.0185 \\
(0.0189)\end{array}$ & $\begin{array}{c}0.0772 * * * \\
(0.0206)\end{array}$ & $\begin{array}{c}0.0956 * * * \\
(0.0100)\end{array}$ \\
\hline Age $>49$ & $\begin{array}{c}0.437 * * * \\
(0.0750)\end{array}$ & $\begin{array}{c}-0.333 * * * \\
(0.0757)\end{array}$ & $\begin{array}{l}0.104 * * * \\
(0.00992)\end{array}$ & $\begin{array}{l}-0.0740 \\
(0.0668)\end{array}$ & $\begin{array}{c}0.272 * * * \\
(0.0663)\end{array}$ & $\begin{array}{c}0.198 * * * \\
(0.0103)\end{array}$ & $\begin{array}{c}0.213^{* * *} \\
(0.0351)\end{array}$ & $\begin{array}{c}0.0332 \\
(0.0348)\end{array}$ & $\begin{array}{c}0.246^{* * *} \\
(0.0270)\end{array}$ \\
\hline Nationalities & & YES & & YES & & YES & & YES & \\
\hline Observations & 14,791 & 14,791 & 14,791 & 14,814 & 14,814 & 14,814 & 14,814 & 14,814 & 14,814 \\
\hline
\end{tabular}


Table A3 continued - Zero Inflated Ordered Probit estimation with nationality dummies - Marginal effects of selected variables for observing 0 outomes decomposed between non-participation and zero consumption

\begin{tabular}{|c|c|c|c|c|c|c|}
\hline & Concerts & Concerts & Concerts & Theatre & Theatre & Theatre \\
\hline & $\begin{array}{l}\text { Non-participation } \\
\qquad \operatorname{Pr}(r=0)\end{array}$ & $\begin{array}{l}\text { Zero consumption } \\
\operatorname{Pr}(r=1, \tilde{y}=0)\end{array}$ & $\begin{array}{c}\text { Full } \\
\operatorname{Pr}(y=0)\end{array}$ & $\begin{array}{c}\text { Non-participation } \\
\operatorname{Pr}(r=0)\end{array}$ & $\begin{array}{l}\text { Zero consumption } \\
\operatorname{Pr}(r=1, \tilde{y}=0)\end{array}$ & $\begin{array}{c}\text { Full } \\
\operatorname{Pr}(y=0)\end{array}$ \\
\hline Years of migration & $\begin{array}{c}0.00220 \\
(0.00196)\end{array}$ & $\begin{array}{l}-0.00623^{* * *} \\
(0.00209)\end{array}$ & $\begin{array}{c}-0.00403 * * * \\
(0.000628)\end{array}$ & $\begin{array}{l}0.0102 * * * \\
(0.00272)\end{array}$ & $\begin{array}{l}-0.0132 * * * \\
(0.00277)\end{array}$ & $\begin{array}{c}-0.00300 * * * \\
(0.000446)\end{array}$ \\
\hline Difficulty italian language & $\begin{array}{l}-0.00156 \\
(0.0390)\end{array}$ & $\begin{array}{c}0.0824 * * \\
(0.0416)\end{array}$ & $\begin{array}{c}0.0809 * * * \\
(0.0119)\end{array}$ & $\begin{array}{l}-0.0111 \\
(0.0688)\end{array}$ & $\begin{array}{c}0.0492 \\
(0.0691)\end{array}$ & $\begin{array}{c}0.0381 * * * \\
(0.00880)\end{array}$ \\
\hline Intention to remain & $\begin{array}{l}-0.0362 \\
(0.0239)\end{array}$ & $\begin{array}{l}0.00875 \\
(0.0245)\end{array}$ & $\begin{array}{c}-0.0274 * * * \\
(0.00672)\end{array}$ & $\begin{array}{l}-0.0431 \\
(0.0388)\end{array}$ & $\begin{array}{c}0.0162 \\
(0.0390)\end{array}$ & $\begin{array}{c}-0.0269 * * * \\
(0.00507)\end{array}$ \\
\hline Religiosity & $\begin{array}{c}0.0549 * * \\
(0.0248)\end{array}$ & $\begin{array}{c}-0.0805 * * * \\
(0.0266)\end{array}$ & $\begin{array}{l}-0.0255^{* * *} \\
(0.00701)\end{array}$ & $\begin{array}{c}0.101 * * * \\
(0.0308)\end{array}$ & $\begin{array}{c}-0.126 * * * \\
(0.0316)\end{array}$ & $\begin{array}{c}-0.0248 * * * \\
(0.00497)\end{array}$ \\
\hline Female & $\begin{array}{c}-0.0482 * * \\
(0.0229)\end{array}$ & $\begin{array}{c}0.0552 * * \\
(0.0233)\end{array}$ & $\begin{array}{c}0.00696 \\
(0.00705)\end{array}$ & $\begin{array}{c}-0.0595 * * \\
(0.0295)\end{array}$ & $\begin{array}{c}0.0356 \\
(0.0299)\end{array}$ & $\begin{array}{c}-0.0238 * * * \\
(0.00524)\end{array}$ \\
\hline Age $30-39$ & $\begin{array}{c}0.0217 \\
(0.0293)\end{array}$ & $\begin{array}{l}0.00638 \\
(0.0305)\end{array}$ & $\begin{array}{l}0.0281 * * * \\
(0.00926)\end{array}$ & $\begin{array}{l}0.103 * * \\
(0.0458)\end{array}$ & $\begin{array}{l}-0.0891 \\
(0.0458)\end{array}$ & $\begin{array}{l}0.0138 * * \\
(0.00674)\end{array}$ \\
\hline Age $40-49$ & $\begin{array}{l}0.191 * * * \\
(0.0496)\end{array}$ & $\begin{array}{l}-0.137 * * * \\
(0.0491)\end{array}$ & $\begin{array}{l}0.0546^{* * * *} \\
(0.00998)\end{array}$ & $\begin{array}{l}0.200 * * * \\
(0.0597)\end{array}$ & $\begin{array}{c}-0.183 * * * \\
(0.0601)\end{array}$ & $\begin{array}{l}0.0169 * * \\
(0.00739)\end{array}$ \\
\hline Age $>49$ & $\begin{array}{c}0.339 * * * \\
(0.0579)\end{array}$ & $\begin{array}{c}-0.244 * * * \\
(0.0572)\end{array}$ & $\begin{array}{c}0.0951 * * * \\
(0.0103)\end{array}$ & $\begin{array}{c}0.261 * * * \\
(0.0736)\end{array}$ & $\begin{array}{c}-0.241 * * * \\
(0.0734)\end{array}$ & $\begin{array}{l}0.0194 * * \\
(0.00787)\end{array}$ \\
\hline Nationalities & & YES & & & YES & \\
\hline Observations & 14,814 & 14,814 & 14,814 & 14,791 & 14,791 & 14,791 \\
\hline
\end{tabular}


Table A4. Probit estimation with religious group dummies, marginal effects displayed

\begin{tabular}{|c|c|c|c|c|c|c|}
\hline & $\begin{array}{c}\text { (1) } \\
\text { Sport events }\end{array}$ & $\begin{array}{c}(2) \\
\text { Dancing venues }\end{array}$ & $\begin{array}{c}(3) \\
\text { Cinema }\end{array}$ & $\begin{array}{c}\text { (4) } \\
\text { Concerts }\end{array}$ & $\begin{array}{c}\text { (5) } \\
\text { Theatre }\end{array}$ & $\begin{array}{c}(6) \\
\text { Culturally } \\
\text { Inactive } \\
\end{array}$ \\
\hline Years of migration & $\begin{array}{c}0.00344 * * * \\
(0.000635)\end{array}$ & $\begin{array}{c}0.00275 * * * \\
(0.000704)\end{array}$ & $\begin{array}{c}0.00822 * * * \\
(0.000880)\end{array}$ & $\begin{array}{c}0.00412 * * * \\
(0.000676)\end{array}$ & $\begin{array}{c}0.00257 * * * \\
(0.000430)\end{array}$ & $\begin{array}{c}-0.00782 * * * \\
(0.000942)\end{array}$ \\
\hline Muslim & $\begin{array}{c}-0.0429 * * * \\
(0.0138)\end{array}$ & $\begin{array}{c}-0.0889 * * * \\
(0.0150)\end{array}$ & $\begin{array}{l}-0.112 * * * \\
(0.0185)\end{array}$ & $\begin{array}{c}-0.0617 * * * \\
(0.0150)\end{array}$ & $\begin{array}{c}-0.0416 * * * \\
(0.0100)\end{array}$ & $\begin{array}{l}0.113 * * * \\
(0.0202)\end{array}$ \\
\hline Catholic & $\begin{array}{c}0.0202 \\
(0.0144)\end{array}$ & $\begin{array}{l}0.0358 * * \\
(0.0159)\end{array}$ & $\begin{array}{c}0.0594 * * * \\
(0.0192)\end{array}$ & $\begin{array}{c}0.0173 \\
(0.0155)\end{array}$ & $\begin{array}{c}0.0145 \\
(0.0106)\end{array}$ & $\begin{array}{c}-0.0743 * * * \\
(0.0205)\end{array}$ \\
\hline Orthodox & $\begin{array}{l}-0.0146 \\
(0.0139)\end{array}$ & $\begin{array}{l}-0.0190 \\
(0.0152)\end{array}$ & $\begin{array}{l}-0.0180 \\
(0.0186)\end{array}$ & $\begin{array}{c}-0.0336 * * \\
(0.0149)\end{array}$ & $\begin{array}{l}-0.0165 \\
(0.0101)\end{array}$ & $\begin{array}{c}0.0169 \\
(0.0201)\end{array}$ \\
\hline Eastern Religions & $\begin{array}{c}-0.0816 * * * \\
(0.0266)\end{array}$ & $\begin{array}{c}-0.160 * * * \\
(0.0222)\end{array}$ & $\begin{array}{c}-0.233 * * * \\
(0.0333)\end{array}$ & $\begin{array}{c}-0.100 * * * \\
(0.0303)\end{array}$ & $\begin{array}{c}-0.0602 * * * \\
(0.0174)\end{array}$ & $\begin{array}{l}0.240 * * * \\
(0.0437)\end{array}$ \\
\hline Other religion & $\begin{array}{l}-0.0121 \\
(0.0192)\end{array}$ & $\begin{array}{c}-0.0540 * * * \\
(0.0203)\end{array}$ & $\begin{array}{l}-0.00513 \\
(0.0260)\end{array}$ & $\begin{array}{l}0.00652 \\
(0.0214)\end{array}$ & $\begin{array}{l}0.00432 \\
(0.0144)\end{array}$ & $\begin{array}{l}0.00522 \\
(0.0278)\end{array}$ \\
\hline Difficulty italian language & $\begin{array}{c}-0.0777 * * * \\
(0.0123)\end{array}$ & $\begin{array}{c}-0.103 * * * \\
(0.0135)\end{array}$ & $\begin{array}{c}-0.219 * * * \\
(0.0168)\end{array}$ & $\begin{array}{c}-0.0834 * * * \\
(0.0129)\end{array}$ & $\begin{array}{c}-0.0355 * * * \\
(0.00881)\end{array}$ & $\begin{array}{l}0.218 * * * \\
(0.0164)\end{array}$ \\
\hline Intention to remain & $\begin{array}{l}0.0351 * * * \\
(0.00703)\end{array}$ & $\begin{array}{c}0.0407 * * * \\
(0.00750)\end{array}$ & $\begin{array}{c}0.0891 * * * \\
(0.00946)\end{array}$ & $\begin{array}{c}0.0317 * * * \\
(0.00742)\end{array}$ & $\begin{array}{c}0.0272 * * * \\
(0.00501)\end{array}$ & $\begin{array}{c}-0.0837 * * * \\
(0.0101)\end{array}$ \\
\hline Religiosity & $\begin{array}{c}0.0203^{* * * *} \\
(0.00729)\end{array}$ & $\begin{array}{c}-0.0220 * * * \\
(0.00801)\end{array}$ & $\begin{array}{l}-0.00717 \\
(0.00998)\end{array}$ & $\begin{array}{c}0.00242 \\
(0.00778)\end{array}$ & $\begin{array}{c}0.00784 \\
(0.00502)\end{array}$ & $\begin{array}{l}0.00939 \\
(0.0107)\end{array}$ \\
\hline Female & $\begin{array}{c}-0.0982 * * * \\
(0.00722)\end{array}$ & $\begin{array}{c}0.0110 \\
(0.00790)\end{array}$ & $\begin{array}{c}0.0511 * * * \\
(0.0101)\end{array}$ & $\begin{array}{c}2.08 \mathrm{e}-06 \\
(0.00777)\end{array}$ & $\begin{array}{c}0.0291 * * * \\
(0.00514)\end{array}$ & $\begin{array}{l}-0.0133 \\
(0.0109)\end{array}$ \\
\hline Age $30-39$ & $\begin{array}{c}-0.0303 * * * \\
(0.00989)\end{array}$ & $\begin{array}{c}-0.0970 * * * \\
(0.0111)\end{array}$ & $\begin{array}{c}-0.120 * * * \\
(0.0129)\end{array}$ & $\begin{array}{c}-0.0280 * * * \\
(0.0102)\end{array}$ & $\begin{array}{l}-0.00842 \\
(0.00664)\end{array}$ & $\begin{array}{c}0.0947 * * * \\
(0.0130)\end{array}$ \\
\hline Age $40-49$ & $\begin{array}{c}-0.0460 * * * \\
(0.0109)\end{array}$ & $\begin{array}{c}-0.141 * * * \\
(0.0119)\end{array}$ & $\begin{array}{c}-0.200 * * * \\
(0.0140)\end{array}$ & $\begin{array}{c}-0.0472 * * * \\
(0.0113)\end{array}$ & $\begin{array}{c}-0.0127 \\
(0.00735)\end{array}$ & $\begin{array}{c}0.176 * * * \\
(0.0145)\end{array}$ \\
\hline Age $>49$ & $\begin{array}{c}-0.108 * * * \\
(0.0106)\end{array}$ & $\begin{array}{c}-0.210 * * * \\
(0.0112)\end{array}$ & $\begin{array}{c}-0.289 * * * \\
(0.0140)\end{array}$ & $\begin{array}{c}-0.0927 * * * \\
(0.0114)\end{array}$ & $\begin{array}{c}-0.0137 \\
(0.00784)\end{array}$ & $\begin{array}{l}0.291 * * * \\
(0.0153)\end{array}$ \\
\hline Married & $\begin{array}{c}-0.0214 * * * \\
(0.00739)\end{array}$ & $\begin{array}{c}-0.0917 * * * \\
(0.00779)\end{array}$ & $\begin{array}{c}-0.0542 * * * \\
(0.00984)\end{array}$ & $\begin{array}{c}-0.0495 * * * \\
(0.00772)\end{array}$ & $\begin{array}{c}-0.0153 * * * \\
(0.00505)\end{array}$ & $\begin{array}{c}0.0845^{* * *} \\
(0.0106)\end{array}$ \\
\hline Children & $\begin{array}{c}-0.0705^{* * *} \\
(0.00777)\end{array}$ & $\begin{array}{l}-0.145^{* * * *} \\
(0.00798)\end{array}$ & $\begin{array}{c}-0.159 * * * \\
(0.0103)\end{array}$ & $\begin{array}{c}-0.0922 * * * \\
(0.00808)\end{array}$ & $\begin{array}{c}-0.0303 * * * \\
(0.00529)\end{array}$ & $\begin{array}{c}0.170 * * * \\
(0.0113)\end{array}$ \\
\hline Primary education & $\begin{array}{c}0.0126 \\
(0.0146)\end{array}$ & $\begin{array}{l}-0.0160 \\
(0.0181)\end{array}$ & $\begin{array}{c}0.0254 \\
(0.0215)\end{array}$ & $\begin{array}{l}0.00590 \\
(0.0160)\end{array}$ & $\begin{array}{c}0.0201 \\
(0.0109)\end{array}$ & $\begin{array}{l}-0.0220 \\
(0.0243)\end{array}$ \\
\hline Lower-secondary education & $\begin{array}{c}0.0442 * * * \\
(0.0112)\end{array}$ & $\begin{array}{l}0.00598 \\
(0.0142)\end{array}$ & $\begin{array}{c}0.0729 * * * \\
(0.0163)\end{array}$ & $\begin{array}{c}0.0253 * * \\
(0.0123)\end{array}$ & $\begin{array}{c}0.0212 * * * \\
(0.00787)\end{array}$ & $\begin{array}{c}-0.0652 * * * \\
(0.0185)\end{array}$ \\
\hline Upper-secondary education & $\begin{array}{c}0.0697 * * * \\
(0.0112)\end{array}$ & $\begin{array}{c}0.0282 * * \\
(0.0141)\end{array}$ & $\begin{array}{c}0.132 * * * \\
(0.0161)\end{array}$ & $\begin{array}{c}0.0675 * * * \\
(0.0124)\end{array}$ & $\begin{array}{c}0.0271 * * * \\
(0.00771)\end{array}$ & $\begin{array}{c}-0.127 * * * \\
(0.0182)\end{array}$ \\
\hline Tertiary education & $\begin{array}{c}0.0895 * * * \\
(0.0153)\end{array}$ & $\begin{array}{c}0.0135 \\
(0.0172)\end{array}$ & $\begin{array}{l}0.194 * * * \\
(0.0208)\end{array}$ & $\begin{array}{l}0.138 * * * \\
(0.0170)\end{array}$ & $\begin{array}{c}0.0854 * * * \\
(0.0117)\end{array}$ & $\begin{array}{c}-0.203 * * * \\
(0.0224)\end{array}$ \\
\hline Managers & $\begin{array}{l}0.00947 \\
(0.0422)\end{array}$ & $\begin{array}{c}0.0686 \\
(0.0490)\end{array}$ & $\begin{array}{c}0.0855 \\
(0.0577)\end{array}$ & $\begin{array}{c}0.0158 \\
(0.0441)\end{array}$ & $\begin{array}{c}0.0842 * * \\
(0.0413)\end{array}$ & $\begin{array}{c}-0.110 \\
(0.0591)\end{array}$ \\
\hline Professionals & $\begin{array}{c}0.0615 \\
(0.0319)\end{array}$ & $\begin{array}{c}0.0495 \\
(0.0312)\end{array}$ & $\begin{array}{l}0.209 * * * \\
(0.0409)\end{array}$ & $\begin{array}{l}0.261 * * * \\
(0.0390)\end{array}$ & $\begin{array}{c}0.177 * * * \\
(0.0328)\end{array}$ & $\begin{array}{c}-0.291 * * * \\
(0.0381)\end{array}$ \\
\hline Technicians & $\begin{array}{l}-0.00232 \\
(0.0219)\end{array}$ & $\begin{array}{c}0.0632 * * \\
(0.0250)\end{array}$ & $\begin{array}{c}0.122 * * * \\
(0.0313)\end{array}$ & $\begin{array}{c}0.0988 * * * \\
(0.0262)\end{array}$ & $\begin{array}{c}0.0774 * * * \\
(0.0203)\end{array}$ & $\begin{array}{c}-0.133 * * * \\
(0.0319)\end{array}$ \\
\hline
\end{tabular}




\begin{tabular}{|c|c|c|c|c|c|c|}
\hline Clerks & $\begin{array}{c}0.0462 \\
(0.0291)\end{array}$ & $\begin{array}{c}0.0720 * * \\
(0.0303)\end{array}$ & $\begin{array}{c}0.105 * * * \\
(0.0379)\end{array}$ & $\begin{array}{c}0.0713 * * \\
(0.0307)\end{array}$ & $\begin{array}{c}0.0225 \\
(0.0207)\end{array}$ & $\begin{array}{c}-0.146 * * * \\
(0.0389)\end{array}$ \\
\hline Service and sales & $\begin{array}{c}-0.0236 * * \\
(0.00984)\end{array}$ & $\begin{array}{c}0.0357 * * * \\
(0.0102)\end{array}$ & $\begin{array}{l}0.00269 \\
(0.0128)\end{array}$ & $\begin{array}{c}-0.000600 \\
(0.0100)\end{array}$ & $\begin{array}{c}-0.0177 * * * \\
(0.00660)\end{array}$ & $\begin{array}{l}-0.0132 \\
(0.0138)\end{array}$ \\
\hline Skilled craft and agriculture & $\begin{array}{c}-0.0449 * * * \\
(0.00994)\end{array}$ & $\begin{array}{c}0.0230 * * \\
(0.0115)\end{array}$ & $\begin{array}{l}-0.0148 \\
(0.0143)\end{array}$ & $\begin{array}{c}-0.0256^{* *} \\
(0.0108)\end{array}$ & $\begin{array}{c}-0.0301 * * * \\
(0.00738)\end{array}$ & $\begin{array}{l}0.00148 \\
(0.0154)\end{array}$ \\
\hline Plant and machine operators & $\begin{array}{l}-0.00287 \\
(0.0171)\end{array}$ & $\begin{array}{c}0.0557 * * * \\
(0.0203)\end{array}$ & $\begin{array}{c}0.0118 \\
(0.0233)\end{array}$ & $\begin{array}{c}-0.000896 \\
(0.0182)\end{array}$ & $\begin{array}{c}-0.0383 * * * \\
(0.0106)\end{array}$ & $\begin{array}{l}-0.0385 \\
(0.0245)\end{array}$ \\
\hline Elementary occupations & $\begin{array}{c}-0.0595 * * * \\
(0.00886)\end{array}$ & $\begin{array}{c}-0.0160 \\
(0.00916)\end{array}$ & $\begin{array}{c}-0.0721 * * * \\
(0.0117)\end{array}$ & $\begin{array}{c}-0.0321 * * * \\
(0.00927)\end{array}$ & $\begin{array}{c}-0.0376 * * * \\
(0.00601)\end{array}$ & $\begin{array}{c}0.0513 * * * \\
(0.0130)\end{array}$ \\
\hline North-East & $\begin{array}{l}0.00105 \\
(0.0101)\end{array}$ & $\begin{array}{c}-0.0440 * * * \\
(0.0113)\end{array}$ & $\begin{array}{c}-0.0536 * * * \\
(0.0144)\end{array}$ & $\begin{array}{c}0.0190 \\
(0.0106)\end{array}$ & $\begin{array}{c}0.00700 \\
(0.00735)\end{array}$ & $\begin{array}{c}0.0327 * * \\
(0.0152)\end{array}$ \\
\hline Centre & $\begin{array}{c}0.0419 * * * \\
(0.0108)\end{array}$ & $\begin{array}{l}0.00846 \\
(0.0119)\end{array}$ & $\begin{array}{l}0.00820 \\
(0.0147)\end{array}$ & $\begin{array}{c}0.0186 \\
(0.0106)\end{array}$ & $\begin{array}{c}0.0221 * * * \\
(0.00756)\end{array}$ & $\begin{array}{l}-0.0177 \\
(0.0153)\end{array}$ \\
\hline South & $\begin{array}{c}0.00132 \\
(0.00872)\end{array}$ & $\begin{array}{c}-0.0358 * * * \\
(0.00989)\end{array}$ & $\begin{array}{c}-0.0887 * * * \\
(0.0122)\end{array}$ & $\begin{array}{c}0.0369 * * * \\
(0.00912)\end{array}$ & $\begin{array}{l}-0.00796 \\
(0.00594)\end{array}$ & $\begin{array}{c}0.0801 * * * \\
(0.0130)\end{array}$ \\
\hline Municipality $<10,000$ & $\begin{array}{l}0.0206 * * \\
(0.00902)\end{array}$ & $\begin{array}{c}-0.0388 * * * \\
(0.0101)\end{array}$ & $\begin{array}{c}-0.0868 * * * \\
(0.0126)\end{array}$ & $\begin{array}{c}0.0190 \\
(0.00987)\end{array}$ & $\begin{array}{l}-0.0142 * * \\
(0.00666)\end{array}$ & $\begin{array}{c}0.0745 * * * \\
(0.0137)\end{array}$ \\
\hline Municipality $>10,000$ & $\begin{array}{c}0.0323 * * * \\
(0.00777)\end{array}$ & $\begin{array}{c}-0.0193 * * \\
(0.00893)\end{array}$ & $\begin{array}{c}-0.0393 * * * \\
(0.0112)\end{array}$ & $\begin{array}{l}0.0169 * * \\
(0.00835)\end{array}$ & $\begin{array}{l}-0.0127 * * \\
(0.00579)\end{array}$ & $\begin{array}{c}0.0340 * * * \\
(0.0119)\end{array}$ \\
\hline Observations & 13,732 & 13,752 & 13,752 & 13,752 & 13,752 & 13,732 \\
\hline Log Pseudo-likelihood & -5792 & -5932 & -7447 & -6163 & -3682 & -8206 \\
\hline Wald & 1016 & 2414 & 2752 & 1139 & 915.8 & 2585 \\
\hline Pseudo R2 & 0.0806 & 0.169 & 0.156 & 0.0846 & 0.111 & 0.136 \\
\hline
\end{tabular}

Standard errors in parentheses: $* * * \mathrm{p}<0.01, * * \mathrm{p}<0.05, * \mathrm{p}<0.1$ 
Table A5. Probit estimation with linguistic proximity, marginal effects displayed

\begin{tabular}{|c|c|c|c|c|c|c|}
\hline & $\begin{array}{c}\text { (1) } \\
\text { Sport events }\end{array}$ & $\begin{array}{c}(2) \\
\text { Dancing venues }\end{array}$ & $\begin{array}{c}(3) \\
\text { Cinema }\end{array}$ & $\begin{array}{c}\text { (4) } \\
\text { Concerts }\end{array}$ & $\begin{array}{c}\text { (5) } \\
\text { Theatre }\end{array}$ & $\begin{array}{c}(6) \\
\text { Culturally } \\
\text { Inactive } \\
\end{array}$ \\
\hline Years of migration & $\begin{array}{c}0.00377 * * * \\
(0.000715)\end{array}$ & $\begin{array}{c}0.00258 * * * \\
(0.000802)\end{array}$ & $\begin{array}{c}0.00924 * * * \\
(0.00100)\end{array}$ & $\begin{array}{c}0.00444 * * * \\
(0.000751)\end{array}$ & $\begin{array}{c}0.00186 * * * \\
(0.000470)\end{array}$ & $\begin{array}{c}-0.00811 \text { *** } \\
(0.00108)\end{array}$ \\
\hline Linguistic proximity & $\begin{array}{c}0.0674 * * * \\
(0.0205)\end{array}$ & $\begin{array}{c}0.103 * * * \\
(0.0219)\end{array}$ & $\begin{array}{c}0.160 * * * \\
(0.0277)\end{array}$ & $\begin{array}{l}-0.00313 \\
(0.0211)\end{array}$ & $\begin{array}{c}0.000839 \\
(0.0132)\end{array}$ & $\begin{array}{c}-0.130 * * * \\
(0.0304)\end{array}$ \\
\hline Difficulty italian language & $\begin{array}{c}-0.0771 * * * \\
(0.0133)\end{array}$ & $\begin{array}{c}-0.138 * * * \\
(0.0153)\end{array}$ & $\begin{array}{c}-0.233 * * * \\
(0.0187)\end{array}$ & $\begin{array}{c}-0.107 * * * \\
(0.0142)\end{array}$ & $\begin{array}{c}-0.0360 * * * \\
(0.00892)\end{array}$ & $\begin{array}{c}0.247 * * * \\
(0.0183)\end{array}$ \\
\hline Intention to remain & $\begin{array}{l}0.0311^{* * * *} \\
(0.00763)\end{array}$ & $\begin{array}{l}0.0417 * * * \\
(0.00826)\end{array}$ & $\begin{array}{c}0.0788 * * * \\
(0.0104)\end{array}$ & $\begin{array}{r}0.0333 * * * \\
(0.00796)\end{array}$ & $\begin{array}{l}0.0255 * * * \\
(0.00519)\end{array}$ & $\begin{array}{c}-0.0765 * * * \\
(0.0112)\end{array}$ \\
\hline Religiosity & $\begin{array}{l}0.0359 * * * \\
(0.00785)\end{array}$ & $\begin{array}{l}-0.00425 \\
(0.00874)\end{array}$ & $\begin{array}{c}0.0329 * * * \\
(0.0109)\end{array}$ & $\begin{array}{c}0.0134 \\
(0.00827)\end{array}$ & $\begin{array}{c}0.0179 * * * \\
(0.00502)\end{array}$ & $\begin{array}{c}-0.0248^{* *} \\
(0.0119)\end{array}$ \\
\hline Female & $\begin{array}{c}-0.0934 * * * \\
(0.00776)\end{array}$ & $\begin{array}{c}0.0162 \\
(0.00862)\end{array}$ & $\begin{array}{c}0.0662 * * * \\
(0.0110)\end{array}$ & $\begin{array}{c}0.0125 \\
(0.00827)\end{array}$ & $\begin{array}{l}0.0321 * * * \\
(0.00531)\end{array}$ & $\begin{array}{c}-0.0249 * * \\
(0.0120)\end{array}$ \\
\hline Age $30-39$ & $\begin{array}{c}-0.0255^{* *} \\
(0.0106)\end{array}$ & $\begin{array}{c}-0.0942 * * * \\
(0.0120)\end{array}$ & $\begin{array}{c}-0.117 * * * \\
(0.0142)\end{array}$ & $\begin{array}{c}-0.0213 * * \\
(0.0108)\end{array}$ & $\begin{array}{l}-0.00335 \\
(0.00688)\end{array}$ & $\begin{array}{c}0.0962 * * * \\
(0.0144)\end{array}$ \\
\hline Age $40-49$ & $\begin{array}{c}-0.0446 * * * \\
(0.0116)\end{array}$ & $\begin{array}{c}-0.134 * * * \\
(0.0128)\end{array}$ & $\begin{array}{c}-0.206^{* * *} \\
(0.0150)\end{array}$ & $\begin{array}{c}-0.0427 * * * \\
(0.0118)\end{array}$ & $\begin{array}{l}-0.0151 * * \\
(0.00734)\end{array}$ & $\begin{array}{c}0.186^{* * *} \\
(0.0159)\end{array}$ \\
\hline Age $>49$ & $\begin{array}{c}-0.0987 * * * \\
(0.0114)\end{array}$ & $\begin{array}{c}-0.194 * * * \\
(0.0123)\end{array}$ & $\begin{array}{c}-0.290 * * * \\
(0.0150)\end{array}$ & $\begin{array}{c}-0.0808 * * * \\
(0.0121)\end{array}$ & $\begin{array}{c}-0.0157 * * \\
(0.00790)\end{array}$ & $\begin{array}{c}0.289 * * * \\
(0.0169)\end{array}$ \\
\hline Married & $\begin{array}{c}-0.0345 * * * \\
(0.00817)\end{array}$ & $\begin{array}{l}-0.102 * * * \\
(0.00869)\end{array}$ & $\begin{array}{c}-0.0765 * * * \\
(0.0109)\end{array}$ & $\begin{array}{c}-0.0497 * * * \\
(0.00838)\end{array}$ & $\begin{array}{c}-0.0208 * * * \\
(0.00530)\end{array}$ & $\begin{array}{c}0.106 * * * \\
(0.0119)\end{array}$ \\
\hline Children & $\begin{array}{c}-0.0688 * * * \\
(0.00858)\end{array}$ & $\begin{array}{c}-0.146 * * * \\
(0.00890)\end{array}$ & $\begin{array}{c}-0.156^{* * * *} \\
(0.0115)\end{array}$ & $\begin{array}{c}-0.0949 * * * \\
(0.00875)\end{array}$ & $\begin{array}{c}-0.0208 * * * \\
(0.00558)\end{array}$ & $\begin{array}{c}0.170 * * * \\
(0.0126)\end{array}$ \\
\hline Primary education & $\begin{array}{l}0.00548 \\
(0.0155)\end{array}$ & $\begin{array}{l}-0.0237 \\
(0.0193)\end{array}$ & $\begin{array}{c}0.0318 \\
(0.0235)\end{array}$ & $\begin{array}{c}0.0110 \\
(0.0163)\end{array}$ & $\begin{array}{c}0.0215 * * \\
(0.0108)\end{array}$ & $\begin{array}{l}-0.0170 \\
(0.0269)\end{array}$ \\
\hline Lower-secondary education & $\begin{array}{c}0.0462 * * * \\
(0.0122)\end{array}$ & $\begin{array}{c}0.0147 \\
(0.0157)\end{array}$ & $\begin{array}{c}0.0792 * * * \\
(0.0178)\end{array}$ & $\begin{array}{c}0.0384 * * * \\
(0.0125)\end{array}$ & $\begin{array}{c}0.0241 * * * \\
(0.00760)\end{array}$ & $\begin{array}{c}-0.0782 * * * \\
(0.0206)\end{array}$ \\
\hline Upper-secondary education & $\begin{array}{c}0.0668^{* * * *} \\
(0.0122)\end{array}$ & $\begin{array}{c}0.0343 * * \\
(0.0156)\end{array}$ & $\begin{array}{c}0.143 * * * \\
(0.0176)\end{array}$ & $\begin{array}{c}0.0833 * * * \\
(0.0127)\end{array}$ & $\begin{array}{c}0.0303 * * * \\
(0.00747)\end{array}$ & $\begin{array}{c}-0.148 * * * \\
(0.0203)\end{array}$ \\
\hline Tertiary education & $\begin{array}{c}0.0896^{* * * *} \\
(0.0176)\end{array}$ & $\begin{array}{c}0.0246 \\
(0.0198)\end{array}$ & $\begin{array}{c}0.189 * * * \\
(0.0238)\end{array}$ & $\begin{array}{c}0.143 * * * \\
(0.0188)\end{array}$ & $\begin{array}{c}0.0645 * * * \\
(0.0119)\end{array}$ & $\begin{array}{c}-0.200 * * * \\
(0.0260)\end{array}$ \\
\hline Managers & $\begin{array}{l}-0.0567 \\
(0.0418)\end{array}$ & $\begin{array}{c}0.0219 \\
(0.0554)\end{array}$ & $\begin{array}{c}0.0453 \\
(0.0690)\end{array}$ & $\begin{array}{l}-0.0624 \\
(0.0428)\end{array}$ & $\begin{array}{c}0.0416 \\
(0.0457)\end{array}$ & $\begin{array}{l}-0.0698 \\
(0.0718)\end{array}$ \\
\hline Professionals & $\begin{array}{l}0.174 * * \\
(0.0751)\end{array}$ & $\begin{array}{c}0.0965 \\
(0.0701)\end{array}$ & $\begin{array}{c}0.284 * * * \\
(0.0858)\end{array}$ & $\begin{array}{c}0.300 * * * \\
(0.0802)\end{array}$ & $\begin{array}{c}0.229 * * * \\
(0.0710)\end{array}$ & $\begin{array}{c}-0.472 * * * \\
(0.0545)\end{array}$ \\
\hline Technicians & $\begin{array}{l}0.00305 \\
(0.0283)\end{array}$ & $\begin{array}{c}0.0651 * * \\
(0.0317)\end{array}$ & $\begin{array}{c}0.119 * * * \\
(0.0402)\end{array}$ & $\begin{array}{c}0.101 * * * \\
(0.0334)\end{array}$ & $\begin{array}{c}0.0681 * * * \\
(0.0246)\end{array}$ & $\begin{array}{c}-0.140 * * * \\
(0.0417)\end{array}$ \\
\hline Clerks & $\begin{array}{c}0.0399 \\
(0.0353)\end{array}$ & $\begin{array}{c}0.0989 * * \\
(0.0390)\end{array}$ & $\begin{array}{c}0.156 * * * \\
(0.0478)\end{array}$ & $\begin{array}{c}0.0863 * * \\
(0.0386)\end{array}$ & $\begin{array}{l}-0.00503 \\
(0.0209)\end{array}$ & $\begin{array}{c}-0.185^{* * *} \\
(0.0483)\end{array}$ \\
\hline Service and sales & $\begin{array}{c}-0.0310 * * * \\
(0.0104)\end{array}$ & $\begin{array}{c}0.0388 * * * \\
(0.0110)\end{array}$ & $\begin{array}{c}0.0158 \\
(0.0138)\end{array}$ & $\begin{array}{l}0.00442 \\
(0.0106)\end{array}$ & $\begin{array}{c}-0.0121 \\
(0.00683)\end{array}$ & $\begin{array}{c}-0.0372 * * \\
(0.0151)\end{array}$ \\
\hline Skilled craft and agriculture & $\begin{array}{c}-0.0451 * * * \\
(0.0106)\end{array}$ & $\begin{array}{c}0.0314 * * \\
(0.0123)\end{array}$ & $\begin{array}{c}0.000230 \\
(0.0154)\end{array}$ & $\begin{array}{l}-0.0146 \\
(0.0115)\end{array}$ & $\begin{array}{c}-0.0205 * * * \\
(0.00772)\end{array}$ & $\begin{array}{l}-0.0162 \\
(0.0168)\end{array}$ \\
\hline Plant and machine operators & $\begin{array}{l}0.00532 \\
(0.0193)\end{array}$ & $\begin{array}{c}0.0910 * * * \\
(0.0237)\end{array}$ & $\begin{array}{c}0.0487 \\
(0.0265)\end{array}$ & $\begin{array}{c}0.0295 \\
(0.0211)\end{array}$ & $\begin{array}{c}-0.0352 * * * \\
(0.0109)\end{array}$ & $\begin{array}{c}-0.0912 * * * \\
(0.0279)\end{array}$ \\
\hline Elementary occupations & $\begin{array}{c}-0.0460 * * * \\
(0.00992)\end{array}$ & $\begin{array}{c}-0.00780 \\
(0.0101)\end{array}$ & $\begin{array}{c}-0.0514 * * * \\
(0.0130)\end{array}$ & $\begin{array}{c}-0.0271 * * * \\
(0.00995)\end{array}$ & $\begin{array}{c}-0.0287 * * * \\
(0.00632)\end{array}$ & $\begin{array}{c}0.0242 \\
(0.0145)\end{array}$ \\
\hline
\end{tabular}




\begin{tabular}{|c|c|c|c|c|c|c|}
\hline North-East & $\begin{array}{l}-0.00508 \\
(0.0114)\end{array}$ & $\begin{array}{c}-0.0554 * * * \\
(0.0129)\end{array}$ & $\begin{array}{l}-0.0300 \\
(0.0166)\end{array}$ & $\begin{array}{c}0.0208 \\
(0.0116)\end{array}$ & $\begin{array}{c}0.0126 \\
(0.00776)\end{array}$ & $\begin{array}{c}0.0237 \\
(0.0177)\end{array}$ \\
\hline \multirow[t]{2}{*}{ Centre } & $0.0436 * * *$ & 0.00732 & 0.0224 & $0.0300 * * *$ & $0.0282 * * *$ & -0.0330 \\
\hline & $(0.0118)$ & $(0.0131)$ & $(0.0160)$ & $(0.0112)$ & $(0.00767)$ & $(0.0170)$ \\
\hline \multirow[t]{2}{*}{ South } & -0.00277 & $-0.0400 * * *$ & $-0.0876 * * *$ & $0.0416 * * *$ & -0.00161 & $0.0838 * * *$ \\
\hline & $(0.00974)$ & $(0.0113)$ & $(0.0137)$ & $(0.00982)$ & $(0.00606)$ & $(0.0149)$ \\
\hline \multirow[t]{2}{*}{ Municipality $<10,000$} & $0.0193 * *$ & $-0.0509 * * *$ & $-0.102 * * *$ & 0.0146 & $-0.0215 * * *$ & $0.0778 * * *$ \\
\hline & $(0.00978)$ & $(0.0112)$ & $(0.0140)$ & $(0.0107)$ & $(0.00704)$ & $(0.0153)$ \\
\hline Municipality $>10,000$ & $\begin{array}{c}0.0304 * * * \\
(0.00852)\end{array}$ & $\begin{array}{c}-0.0287 * * * \\
(0.0101)\end{array}$ & $\begin{array}{c}-0.0569 * * * \\
(0.0126)\end{array}$ & $\begin{array}{c}0.0104 \\
(0.00909)\end{array}$ & $\begin{array}{c}-0.0189 * * * \\
(0.00629)\end{array}$ & $\begin{array}{c}0.0415 * * * \\
(0.0134)\end{array}$ \\
\hline Observations & 11,019 & 11,035 & 11,035 & 11,035 & 11,035 & 11,019 \\
\hline Log Pseudo-likelihood & -4475 & -4671 & -5892 & -4726 & -2628 & -6593 \\
\hline Wald & 829.3 & 1954 & 2133 & 803.1 & 432.1 & 1994 \\
\hline Pseudo R2 & 0.0848 & 0.173 & 0.153 & 0.0783 & 0.0760 & 0.131 \\
\hline
\end{tabular}

Standard errors in parentheses: $* * * \mathrm{p}<0.01, * * \mathrm{p}<0.05, * \mathrm{p}<0.1$ 
www.celsi.sk
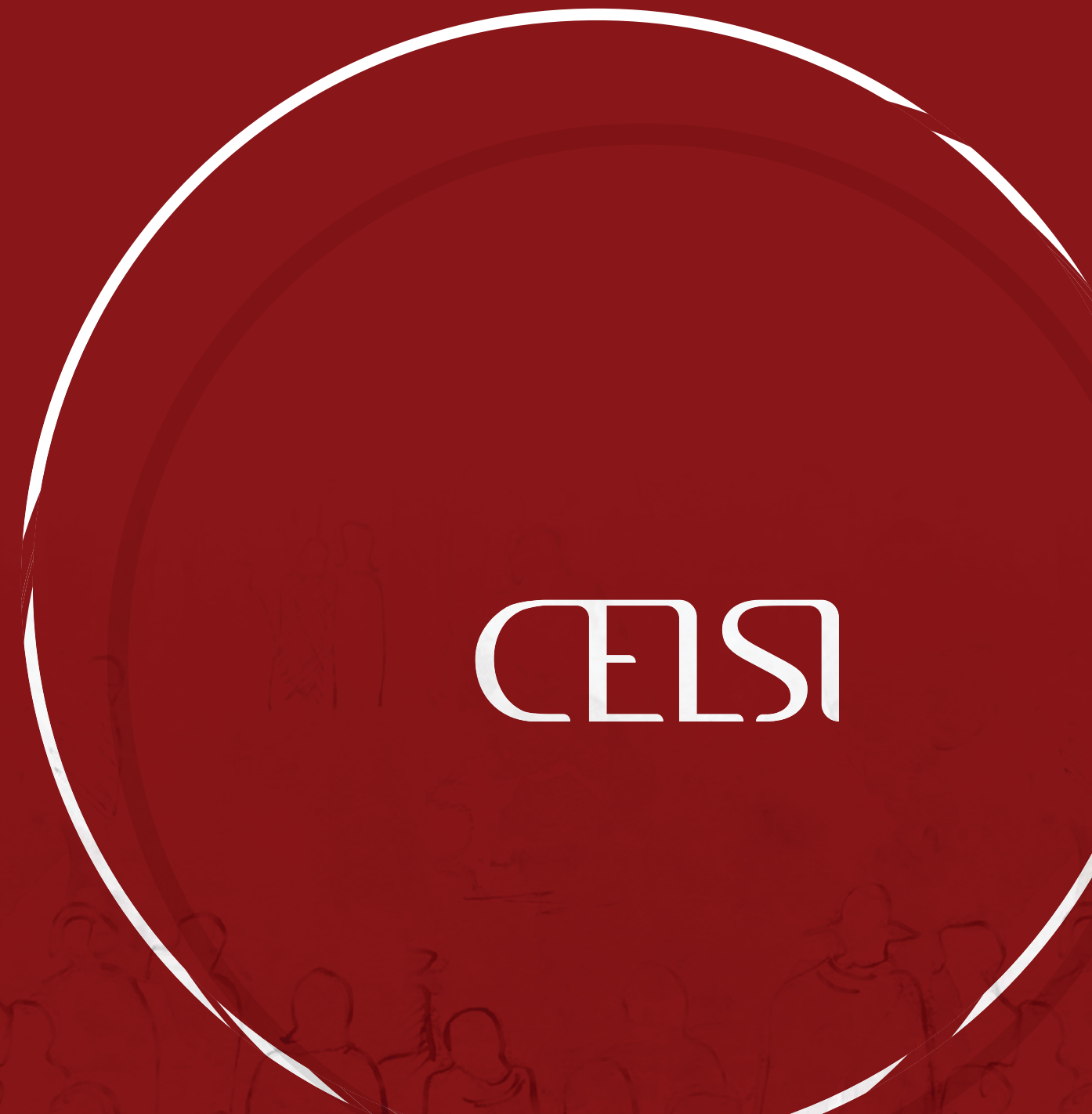